\title{
1 How do big rivers come to be different?
}

3 Philip J. Ashworth ${ }^{\mathrm{a}^{*}}$ and John Lewin ${ }^{\mathrm{b}}$

5 a Division of Geography and Geology, School of Environment and Technology, University of

6 Brighton, Brighton, Sussex, BN2 4GJ, UK (E-mail: p.ashworth@brighton.ac.uk)

$7 \quad{ }^{b}$ Institute of Geography and Earth Sciences, Aberystwyth University, Llandinam Building,

8 Penglais Campus, Aberystwyth, SY23 3DB, UK (E-mail: john1lewin@btinternet.com)

$12{ }^{*}$ Corresponding author at: Division of Geography and Geology, School of Environment and

13 Technology, University of Brighton, Brighton, Sussex, BN2 4GJ, UK, Tel: +44 1273 642266,

14 Fax: +44 1273642285

15 E-mail address: p.ashworth@brighton.ac.uk

\section{ABSTRACT}

Big rivers dominate the world's continental surface, yet we are still learning about how they

20 operate and whether they are explicably different, not only from each other, but also from

21 smaller rivers. This paper uses global satellite imagery and ground field-experience to explain

22 and illustrate why and how big rivers are strongly differentiated. 
25 fluvial functions. Alluvial settings are dependent on mainstream and tributary inputs of water

26 and sediment, but big river channel pattern variety is determined by contrasts in sediment

27 feed-rates and differences in the rates and routes of sediment exchange. Four modes of

28 alluvial exchange are recognised: (i) deposition on the floodplain (e.g., levees, infilled

29 palaeochannels, floodbasins), (ii) exchanges involving main channels (e.g., bank erosion and

30 accretion), (iii) deposition within main channels (e.g. bedforms from metres to 10 s of

31 kilometres in size), and (iv) material input from tributaries (sediment-rich or sediment-poor).

32 Different combinations of sedimentation activity lead to floodplain morphologies for big rivers

33 that can be classified into four types: (i) lacustrine-dominated, (ii) mainstream-dominated, (iii)

34 tributary or accessory-stream dominated, and (iv) confined or bedrock-dominated.

35 Channel patterning involves a range of main-channel, branch and floodplain styles 36 promoted by variable sediment feeds, complex bed sediment transfers, variable lateral

37 sediment exchanges, plural channel systems and incomplete mineral sedimentation of the

38 hydraulic corridors set by tectonics and prior-valley trenching. In some of the world's largest

39 rivers it is accessory and tributary channels, rather than main-river branches, which

40 determine patterns of floodplain morphology. In some big rivers, but certainly not all, ponded

41 lacustrine environments are common, with water bodies that vary from smaller water-filled

42 swales and palaeochannels, to floodbasins and km-scale linear lakes in sediment-dammed

43 tributaries. Organic sedimentation is significant along relatively sediment-poor and laterally-

44 stable large rivers that fail to fill their alluvial corridors. Three case studies are used to

45 illustrate this variability in big river pattern and process: the Ob, Jamuna and Paraná. These

46 rivers are respectively dominated by meandering, braiding and mixed mainstream and

47 accessory channel morphologies. 
Big rivers have some processes and patterns that are different from smaller rivers

49 including: (i) no simple down-valley sequence in control variables and channel pattern, (ii)

50 main channels with high width:depth ratios, (iii) few or no channel-wide unit bars migrating

51 through the main thalwegs, (iv) extensive and low-gradient floodplains that provide space for 52 channel shifting and floodplain sedimentation, (v) long distances between significant

53 tributaries to allow full mixing of water and sediment discharges, (vi) in some places, partially-

54 decoupled channels and floodplains, and (vii) significant floodplain water bodies that readily

55 act as sinks for fine-grained sediment where this is supplied, or organic deposition.

56 Although understanding of contemporary big river patterns requires attention to a range

57 of timescales, including inheritance from sediments of Quaternary age, big rivers do have a

58 distinctive character. The variety of patterns on big rivers may usefully be viewed in terms of

59 sediment systems operating at both the catchment and reach scales. Intra-river variability

60 and internal complexity show the need to understand contrasted sediment supply, through-

61 put and alluvial exchange as determinants of big river morphology and pattern.

64 Keywords: Large rivers, channel patterns, alluvial exchange, floodplains 


\section{Introduction}

For an observer in the field, a river might seem best defined as 'big' in terms of a channel dimension threshold. Upstream of tidal influence, the undivided Amazon can be over

$755 \mathrm{~km}$ wide (e.g., at $\left.3^{\circ} 50^{\prime} \mathrm{S}, 62^{\circ} 26^{\prime} \mathrm{W}\right)$, the Congo $8 \mathrm{~km}$ (e.g., at $\left.2^{\circ} 31^{\prime} \mathrm{S}, 16^{\circ} 10^{\prime} \mathrm{E}\right)$ and the braided Brahmaputra/Jamuna (including exposed bars and temporary islands) even wider at 10-15 km in places (e.g., $24^{\circ} 36^{\prime} \mathrm{N}, 89^{\circ} 44^{\prime} \mathrm{E}$ ). Any river over $1 \mathrm{~km}$ wide could reasonably be described as big (e.g., Sambrook Smith et al., 2009) but in field situations, reach-scale complexity makes morphological sizing somewhat equivocal.

Large alluvial rivers commonly widen and narrow over comparatively short distances.

Abrupt changes in active braidplain width may be caused by flow divergence and 82 convergence through confluence-diffluence units around km-scale bars (e.g., the Paraná at

$8331^{\circ} 33^{\prime} \mathrm{S}, 60^{\circ} 18 \mathrm{~W}$ that narrows from $7 \mathrm{~km}$ to $0.5 \mathrm{~km}$ along a $14 \mathrm{~km}$ reach; see Parsons et al., 84 (2007)), or be controlled by bedrock constriction (e.g., the Mekong at $13^{\circ} 56^{\prime} \mathrm{N}, 105^{\circ} 14^{\prime} \mathrm{E}$; see 85 Gupta (2007)), or as a river pattern forms a network of 'island and node' reaches (e.g., 86 Thorne et al., 1993). Big rivers typically have a hierarchy of mid-channel bars and islands

87 (e.g., Bristow, 1987; Kelly, 2006), some of which may be heavily vegetated (e.g. the Congo 88 River at $1^{\circ} 29^{\prime} \mathrm{N}, 18^{\circ} 60^{\prime} \mathrm{E}$ and the Amazon at $2^{\circ} 59^{\prime} \mathrm{S}, 67^{\circ} 50^{\prime} \mathrm{W}$ ) and at a height that can only

89 be overtopped in out-of-bank flows (Thorne et al., 1993). Divided flows with main and 90 accessory channels are commonplace. Some big rivers can be well-connected to their

91 floodplains, frequently interchanging sediment and water with adjacent wetlands (e.g. the

92 Paraná at $28^{\circ} 22^{\prime} \mathrm{S}, 59^{\circ} 03^{\prime} \mathrm{W}$ and Fly at $7^{\circ} 115^{\prime} \mathrm{S}, 141^{\circ} 11^{\prime} \mathrm{E}$ ), whereas others are essentially

93 disconnected (e.g. Congo River for nearly its entire length of over $2000 \mathrm{~km}$ ) and function as a 
94 single conduit for sediment and water transfer. Major bedforms may also be drowned out at

95 higher flows and exposed at lower ones (e.g. Rio Negro River at $02^{\circ} 44 ' \mathrm{~S}, 60^{\circ} 42^{\prime} \mathrm{W}$ ), so that

96 observational river stage and 'bank' definition are critical for describing channel morphology

97 and style (Kleinhans and Van den Berg, 2011). Finally, extremes of scour depth, which may

98 have significant importance for engineering structures (Mosselman, 2006) and determine

99 preserved sedimentation thickness (e.g., Gibling, 2006; Fielding, 2007), vary in both space

100 and time at the reach scale (e.g., Best and Ashworth, 1997), reaching maximum combing

101 depths (Paola and Borgman, 1991) of $100 \mathrm{~m}$ in the middle Amazon (Sioli, 1984). It is

102 therefore perhaps unsurprising that although widths and depths for some larger rivers appear

103 in hydraulic geometry data sets (e.g., Van den Berg, 1995; Xu, 2004; Latrubesse, 2008),

104 channel dimensions are not what have been used to produce a ranked list of the world's

105 largest rivers. With the changeability and complexities of large river channel geometries, it is

106 far from easy to specify a measure of river morphology on an acceptable comparative basis.

107 In practice, 'big' rivers are identified not by size of channel but in terms of determining

108 factors for which global data are available: catchment area, length, discharge or sediment

109 yield (e.g., Holeman, 1968; Potter, 1978; Milliman and Meade, 1983; Schumm and Winkley,

110 1994; Hovius, 1998; Gupta, 2007). Different data collations show reasonable agreement on

111 lengths and areas, but representative discharge and sediment loads are more difficult

112 because of gauging limitations and data availability (especially for sediment loadings) and the

113 transforming effects of human activity and river regulation (Meade and Parker, 1984; Syvitski

114 et al., 2005; Walling, 2006; Syvitski and Kettner 2011). Water discharge or sediment data

115 from the centuries of 'genetically-modified' fluvial regimes may not represent well the

116 conditions for sedimentation or landform generation that have operated over a longer term 
117 (Gupta, 2007; Wilkinson and McElroy, 2007; Wasson, 2012). For example, Syvitski and 118 Kettner (2011) calculate that the twentieth century global sediment load delivered to the

119 coastal zone has reduced by $15 \%$, although sediment loads vary widely reflecting different 120 stages of industrial development and land-use change in individual river basins. Likewise, 121 Wang et al. (2011) calculate that there has been a $70 \%$ reduction in sediment flux to the 122 ocean since 1000 yr BP from major rivers in East and Southeast Asia (including the Yangtze 123 and Mekong), with an accelerating decrease since the 1950s.

125 sometimes with a notional allowance for bedload, whereas channel patterning necessarily 126 involves bed material transfer (Kleinhans, 2010). In reality, bedload yield is notoriously 127 difficult to measure (Kuhnle, 2007) and in practice sediment load partitioning can be very 128 varied and strongly dependent on local catchment geology (Turowski et al., 2010). A further 129 challenge is that a mean annual discharge (the usual measure adopted) may be less 130 significant for channel patterning than other measures such as formative (channel-full or bar131 top level) discharge, flood magnitude and frequency, or flow duration and annual variability. 132 Despite this, Latrubesse (2008) suggests that 'large' rivers are ones with a mean annual 133 discharge of greater than $1000 \mathrm{~m}^{3} \mathrm{~s}^{-1}$, and 'mega' rivers are greater than $\sim 17000 \mathrm{~m}^{3} \mathrm{~s}^{-1}$.

134 Data sets for catchment size, discharge and suspended sediment yield give different 135 river orderings, and there are no simple relationships between catchment size and 136 discharges of water and sediment (Figs 1A-B). Leaving aside the Amazon, both annual runoff 137 and mean sediment yield of some of the world's largest rivers range over two orders of 138 magnitude (Fig. 1A). Latrubesse's (2008) division of 'large' and 'mega' rivers (equivalent to 13932 and $536 \times 10^{9} \mathrm{~m}^{3} \mathrm{yr}^{-1}$, or $\mathrm{km}^{3} \mathrm{yr}^{-1}$, respectively) does not produce a clear separation (Fig. 
$140 \mathrm{1A}$ ) and those classified as 'mega' rivers in Fig. $1 \mathrm{~A}$ are not all grouped together by catchment 141 area (Fig. 1B). It has been shown that small mountain catchments provide a large proportion 142 of continental sediment yields (Milliman and Syvitski, 1992), and large catchments 143 demonstrate markedly heterogenic behaviour. In some circumstance it may be piedmont 144 Quaternary materials (Church et al., 1989) or lowland agricultural lands (Wilkinson and 145 McElroy, 2007) that dominate sediment supply. On a continental scale, the sourcing, routing 146 and loss of surface-water (from precipitation, evapo-transpiration, groundwater recharge and 147 river flow) is spatially and temporally variable and the supply and throughput of sediment 148 (from erosion, transport, alluvial sequestration and as downstream output) is distinctly non149 linear (Jerolmack and Paola, 2010; Van de Wiel and Coulthard, 2010). Furthermore, there 150 are regional differences in climate, lithology and hydrology that may influence the relationship 151 between drainage area and water discharge (cf. Davidson and North, 2009). So it is 152 unsurprising that there is no simple relationship between river size, sediment yield and 153 drainage area (Figs 1A-B). Ranked lists of the world's largest rivers based on these attributes 154 should therefore be viewed with caution,

$155 \quad$ Earlier research on channel pattern discrimination for smaller rivers has generally 156 been attempted using measures of discharge, gradient, stream power and bed sediment size 157 (e.g., Leopold and Wolman, 1957; Ferguson, 1987; Van den Berg, 1995; Lewin and Brewer, 158 2001). These controlling factors are more pertinent to bed material transfers rather than the 159 sub-capacity suspended sediment and sand loads typical of the world's largest rivers. It has 160 been argued that this whole approach of channel pattern discrimination based on stream 161 power is not fully satisfactory, especially for large anabranching systems that typically have 162 low gradients, fine bed sediment and excess sediment transport capacity (Sarker and 
163 Thorne, 2006; Latrubesse, 2008). Indeed, Kleinhans and Van den Berg (2011) conclude that

164 large anabranching rivers are not clearly empirically or theoretically related to stream power

165 unlike their smaller counterparts. For the world's largest rivers it is contrasts in sediment

166 feed-rates and transfer styles that appear crucial in determining more generally big river

167 channel pattern variety (cf. Smith and Smith, 1984; Church, 2006).

168 Clearly, there is a need to re-assess the intra and inter-variability in big river channel 169 pattern. With the availability of free, downloadable satellite imagery (most courtesy of the

170 United States Geological Survey; http://glovis.usgs.gov/) it is now possible to access remote 171 parts of the globe where many large river basins dominate, and to document the intricate 172 detail of big river channel pattern as well as quantify big river planform development over

173 decadal time-scales. This paper uses examples from the world's largest rivers to: (i) identify 174 the controls on the style of big river channel patterns at a trans-continental scale; (ii) present 175 a new framework for contemporary channel styles of big rivers and set inter- and intra- large 176 river morphological contrasts within a sediment transport schema; (iii) describe pattern 177 evolutions involving channelised flows, bedforms and floodplains over a range of time scales, 178 and (iv) question whether the processes and patterns of large rivers are explicably different, 179 not only from each other, but also from smaller rivers.

\section{Big rivers at a trans-continental scale}

The world's largest rivers are bigger than individual sedimentary basins. Big rivers 184 may extend into sedimentary basins, but they also cross them (e.g. Danube, Yangtze), and

185 have longitudinally-extensive depositional zones (e.g. Congo, Ob). Whilst big rivers play an 186 important role in sorting and sequestering coarse sediment in their proximal reaches, 
187 sometimes represented by a single or series of mega-fans (e.g. Paraguay River, cf. Assine 188 and Silva (2009)), most of the world's largest rivers go beyond so-called 'distributive fluvial

189 systems' or DFS (Hartley et al., 2010; Weissmann et al., 2010; 2011). As Sambrook Smith et 190 al. (2010) and Fielding et al. (in press) note, the rivers and sedimentary basins used to 191 support the concept of DFS (Weissmann et al., 2010; their Fig. 1, p. 39) exclude over 75\% of 192 the Earth's largest rivers (see Fielding et al., in press, their Figure 7). Unlike DFS, big rivers 193 can also include significant reaches dominated by laterally migrating channels, contain 194 channels and floodplains with substantial organic-rich sedimentation and have partially195 decoupled channels and floodplains (Lewin and Ashworth, in press). Put simply, the world's 196 largest rivers are bigger than sedimentary basins alone - they transcend geological terrains 197 and individual depositional basins, and have both sediment-rich and sediment-poor 198 tributaries.

199 At the largest scale, trans-continent sized rivers do not possess unified valley systems 200 created by fluvial erosion but instead involve a series of chains of interlinked domains with 201 contrasting fluvial functions:

203 (i) dominant headwater orogenic-belt sources for sediment and runoff (Milliman and $204 \quad$ Syvitski, 1992);

205 (ii) intramontane and foreland depositional basins and ramps that accumulate large proportions of upstream eroded materials (Miall, 1996; Fielding et al., in press);

(iii) low sediment-yield cratons that may or may not be highly runoff-generating (Latrubesse et al., 2005);

209 (iv) tectonic troughs that funnel and focus runoff and deposition; 
(v) transverse orogens and depositional basins in downstream reaches;

(vi) peri-marine environments that have also been greatly affected by fluctuations in the average level of the sea surface relative to the continents.

Large rivers are composites, many only linked-up together in the recent geological past (Goudie, 2005; see Williams, 2012; his Table 2, p. 2113-2115). From a channel pattern perspective, large rivers are not 'monotonic' like most smaller ones, and they do not have a simple down-channel trend in control variable (e.g. discharge, slope, grain size) and geographical progression through zones of sediment-source, transport and deposition (source-to-sink) as in the small-stream model that has dominated fluvial geomorphology (Schumm, 1977). For larger systems, the extent and down-valley sequencing of functioning domain-chains varies between river systems and their tributaries, and one or more may be missing. Thus, the biggest African rivers are largely cratonic, the Yangtze (Changjiang) and the Danube have depositional basins and gorge sections through mountain zones set transversely across their lower courses, whilst the Ganga basin drainage has right-bank cratonic tributaries and left-bank orogenic ones, but no cratonic middle section. The morphology of trunk valley floors and their feeders are subordinate to these large-scale domains. Sediments and water from major rivers are carried both across their boundaries, and wholly or only partially fill the structural troughs that are available as they pass through. Structural steering is also significant at the local scale, so that the middle course of the Amazon is constrained by fault and fracture patterns (Mertes and Dunne, 2007) as is the alignment of many cratonic river courses (Twidale, 2004). Whilst this variety has been widely appreciated (Potter, 1978; Miall, 1996; 2006; Schumm and Winkley 1994; Gupta, 2007; 
233 Meade, 2007), it seems that some expectable consequences for large-river channel 234 patterning have not been acknowledged.

235 Figure 2 shows in simplified form the possible combinations of functioning domains. This 236 schema broadly follows the typology of Potter (1978) and subsequent variants that have 237 focussed on basin fills (e.g., Miall, 1996; his fig. 11.77). However, the schema in Fig. 2 238 intentionally emphasises the role of tributaries, whether sediment-rich or sediment-poor, and 239 of the dispersal and sediment storage along big river systems that may or may not terminate

240 in well-defined depositional basins. Some large rivers (e.g., south-east Asia where the gorges 241 of the Yangtze, Mekong, Salween and Irrawaddy run side-by-side in fold mountains) have 242 mountain courses for a considerable proportion of their catchments (Fig. 2A). Elsewhere, 243 supply sources may be lateral from a succession of tributaries (Fig. 2B) that allow repeated 244 sediment replenishment (as along the Ganga basin) or at the head of a trunk river (Figs 2C 245 and 2D) but with extensive sediment exchange along an alluvial corridor (e.g., the Amazon).

246 Even within small catchments, tributaries may of course differ in terms of gradient, discharge 247 and sediment character from their trunk streams, but in large basins there may be far greater 248 contrasts between mainstream and tributary sediment and discharge contributions. This can 249 work either way. The Mato Grosso tributaries of the Amazon are sediment-poor and have 250 failed to fill valley trenches related to lower sea levels (Archer, 2005). The Andes-fed Amazon 251 has alluviated its valley across their mouths resulting in ponded, lacustrine tributaries (Rio 252 Tapajós, Rio Xingu) joining the main river. Some lowland Amazonian rainforest rivers (Purus, 253 Juruá) may have higher yields that they extract from Tertiary basin fills (Latrubesse et al., 254 2005). On the other hand, the meandering Yamuna-Ganges trough is relatively sediment255 poor until fed successively by its braided Himalayan tributaries. It is also possible for large 
256 rivers like the Danube to have an alternation between depositional basins and transverse

257 uplands along their courses (Fig. 2E), or even rivers that have few mountainous sediment

258 sources at all (Fig. 2F). Large African rivers can almost reverse the small-river model:

259 upstream plains, with steeper bedrock-controlled and confined courses downstream crossing

260 rifted continental margins (Goudie, 2005).

261 Equally important is the intra-catchment accommodation space available for deposition, 262 ranging from very little (as in gorge sections through transverse mountains), to intermittently 263 flood-inundated transport corridors of considerable length (including cratonic graben 264 structures), and finally to wide lacustrine and other depositional environments in subsiding 265 depositional basins (for continental basin distribution, see Weissmann et al. 2010, their fig. 1,

266 p. 39). Coarser sediments in particular may be removed in proximal aggrading fan 267 environments and on foreland surfaces like the llanos plains of the Orinoco headwaters 268 (Meade, 2007). But even for fine sediment, the potential for basin sedimentation can be 269 considerable, as in the Dongting Lake of the middle Yangtze (Chen et al., 2007).

270 For riparian alluvial corridors, short-term studies of both large (Aalto et al., 2006; Allison et 271 al., 1998; Dunne et al., 1998; Ten Brinke et al., 1998; Goodbred and Kuehl, 1999; Meade et 272 al., 2000; Meade, 2007) and smaller (Lambert and Walling, 1987; Marron, 1992; Walling and 273 Quine, 1993, Gomez et al., 1999) rivers show that within-catchment floodplain deposition is 274 important. Alluvial storage has a buffering effect on sediment flux such that the short-term 275 effects of climatic fluctuations are delayed and evened-out (Métivier and Gaudemer, 1999). 276 Sediment may be remobilized by lateral channel migration, and studies of the Fly and

277 Strickland Rivers in Papua New Guinea have shown that recycling rates as well as supply 278 and sequestration rates account for depositional contrasts between the two rivers (Swanson 
279 et al., 2008). For the Amazon, Dunne et al. (1998) suggested that system-wide alluvial

280 exchanges (into and out of alluvial storage) may exceed downstream sediment fluxes by a

281 factor of two or more.

282 For their size and gross stream powers, big rivers may have relatively low sediment 283 loadings. But, for three reasons, they strongly refine the sediment load during its passage 284 downstream:

1. Intra-catchment depobasin distribution allows for much sediment removal. This may be in aggrading intramontane and foreland areas, or in cratonic depressions. This is supplemented by alluvial storage and exchange along extended riparian corridors;

2. Large areas of their catchments may be low sediment yielding, thus reducing the downstream impacts of high-yielding sources;

3. Major rivers have exceptional length for achieving sediment fining by abrasion, sorting and exchange (Allison et al., 1998; Goodbred and Kuehl, 1999; Aalto et al., 2006; Frings, 2008).

296 Quaternary deposits, or agricultural land), but also on sink distribution (e.g., intra-catchment depositional basins, riparian floodplains, or present-day reservoirs) and availability (i.e.

298 'accommodation'), involved in dispersal loss or sequestration along the way. Whilst erosion 299 loss from uplifting mountains is high, much of this may be deposited in close proximity 300 although the waters of large rivers drain through and beyond depositional basins. The 301 sediment supply/sink balance leaves the down-valley reaches of some large rivers sediment- 
302 rich and others sediment-starved. Furthermore, tropical lowland tributaries that are sediment-

303 poor may nevertheless generate high discharges to produce flooding. Whether or not the

304 fractional catchment input represented by sediment-laden tributaries enters already flooded

305 environments, it can have marked effects on depositional styles. On floodplains, this may

306 involve either widespread sediment advection (e.g., Day et al. 2008) or local bank-side

307 diffusion into wetlands (e.g., Adams et al., 2004; Slingerland and Smith, 2004). Major

308 ephemeral rivers entering drylands may have flood-outs in which both water and sediment

309 are entirely dissipated (Tooth, 1999).

310 Climatic variety adds an extra dimension in terms of both water discharge and sediment

311 yield. The Ganga River experienced five aggradational periods separated by incisional

312 episodes in the past $\sim 100 \mathrm{k}$ years with the timing of incisional periods corresponding broadly

313 with periods of monsoonal intensification (Roy et al., 2012). Other major high-latitude

314 catchments like the Mackenzie have strongly-peaked nival and proglacial runoff regimes and

315 permafrost. Glacigenic sediments are redistributed by rivers that also cross cratonic surfaces

316 stripped of superficial deposits by prior glaciation. For example, Pleistocene ice sheets

317 produced both rearrangement of drainage lines and catastrophic megafloods (Baker, 2007),

318 whilst $90 \%$ of the Huanghe's exceptional sediment load is derived from loess terrains (Wohl,

319 2007). Active hydraulic corridors may be set within suites of Quaternary terraces that may be

320 eroded to provide additional sediment (e.g., Latrubesse and Franzinelli, 2002; Iriondo et al.,

321 2007; Singh, 2007). Alternatively, long reaches of some large rivers may have been in a state

322 of sediment mass-balance equilibrium with general vertical stability of the river and a lack of

323 terraces or a variation in valley-fill depth over the Holocene (e.g. along $1000 \mathrm{~km}$ of the Middle

324 Yukon, see Froese et al., 2005). Present-day river systems may not be analogues for ancient 
325 fluvial deposits produced in different climate regimes and many river patterns are adjusted to,

326 or in the process of adjusting to, the present interglacial conditions (cf. Valente and

327 Latrubesse, 2012; Wasson et al., 2012). In varied and dynamic Quaternary climatic

328 environments, and for reasons additional to tectonic settings, present-day large-river

329 sediment sources and storages involve a mosaic of domains.

\section{Alluvial channel patterns of big rivers}

336 Big rivers show a bewildering range of channel planform - from single to multiple

337 channels, some with bars and islands dominated by lateral accretion and channel migration,

338 yet others with a floodplain that is often dominated by adjacent standing water bodies in a

339 range of size that may be refilled during floods (Fig. 3). Work to distinguish between different

340 alluvial river patterns has been ongoing since the seminal work of Leopold and Wolman

341 (1957) that categorised rivers as braided, meandering or straight. Braided patterns are

342 divided by active bars that are usually ephemeral and submerged at high flow (Ashmore,

343 1991). Numerous descriptive classification schemes have been proposed since the work of

344 Leopold and Wolman (cf. Eaton et al., 2010) that use a plethora of terms and descriptions

345 (e.g., 16 in Brice (1975) and 14 in Schumm (1981)), which are usually organised according to

346 their dependence on sinuosity, degree of braiding or mode of sediment transport (suspended

347 versus bedload). It is now acknowledged that there are at least two other named channel 
348 pattern morphologies besides braided, meandering and straight: (i) wandering rivers that are

349 transitional between meandering and braiding, commonly with islands of greater permanence

350 and large area (Neil, 1973; Carson, 1984; Burge and Lapointe, 2005), and (ii) anastomosing

351 rivers with multiple channels developed in fine-grained sediments, often with lakes and

352 wetlands between levee-flanked channel branches and stable alluvial islands that divide flow

353 up to bankfull (Knighton and Nanson, 1993; Abbado et al., 2005). Anastomosing channels

354 tend to be laterally inactive, although not always the case as described for the Middle

355 Amazon by Rozo et al. (2012). As a separate category of river channel pattern, or more

356 usually at a higher level of classification (Kleinhans and Van den Berg, 2011), is the

357 anabranching river (Rust, 1978; Knighton and Nanson, 1993; Nanson and Knighton, 1996)

358 defined as a system of multiple channels that divide and rejoin. An anabranching river may

359 have individual branches between more permanent islands that have a range of patterns:

360 straight, meandering, braided, wandering or anastomosing (Nanson and Knighton, 1996).

361 Jansen and Nanson (2004) stated that more than $90 \%$ of the world's five largest rivers

362 anabranch along more than $90 \%$ of their total alluvial tracts and Latrubesse (2008) reported

363 that all rivers with mean annual discharges $>17,000 \mathrm{~m}^{3} \mathrm{~s}^{-1}$ anabranch.. However, individual

364 branch channel patterns are determined by the degree of lateral shifting, rate of overbank

365 sedimentation, magnitude of sediment transport capacity and bed material/braiding intensity

366 (Fig. 4). Anabranching itself, as usually defined (e.g., Knighton and Nanson, 1993), is not

367 produced by a single set of processes.

368 Very rarely, where rivers flow into still freshwaters without an appreciable sand load, there

369 are 'archipelagos' of silty levees. These take the form of highly elongate branching ridges

370 paralleling faster-velocity channels within broad water bodies (Figs 5A-B). Such water bodies, 
371 with individual branching levees can run for tens of kilometres, and are found in dammed

372 tributary lakes draining to the Amazon (Archer, 2005; his figure 10, p. 28; Latrubesse and

373 Franzinelli, 2005), in rift valleys in central Africa (e.g., along the Albert Nile in Uganda, $3^{\circ}$

$37432^{\prime} \mathrm{N}, 31^{\circ} 52^{\prime} \mathrm{E}$ ) and very extensively along the lower Ob in Russia (see Section 4.1).

375 Latrubesse and Franzinelli (2005), studying the $275 \mathrm{~km}$-long Mariuá archipelago and the

376 Anavilhanas islands on the Rio Negro in Brazil (Figs 5A-B), describe the development of

377 sandy islands capped with muddy sediments, and then muddy levee 'trees' extending

378 downstream for considerable distances. These may enclose lakes where channels and

379 levees rejoin. Archer (2005) suggests that humic acids and low pH contribute to flocculation

380 of clays and silts in the Rio Negro, and the same probably applies to some craton drainages

381 elsewhere. This is an eventual means for rivers to prograde and 'bridge' water-filled and 382 possibly subsiding basins with levee-lined river passages, with organic materials playing 383 significant depositional roles. However, Latrubesse and Franzinelli (2005) suggest that the

384 Rio Negro features date from former periods of more active sediment input. The upstream

385 Mariuá basin was filled largely with sandy sediments in the Holocene, with the flooded lower

386 Anavilhanas basin (dammed by the Solimões-Amazon) in an arrested state of development

387 and only partially modified with levee-lined channels. Laterally-mobile and low-energy muddy

388 meandering streams have been described elsewhere, involving oblique accretion and post-

389 depositional bank failure (Brooks, 2003), though there is only limited detail available for

390 cohesive muddy-sediment processes in large freshwater rivers (cf. Maroulis and Nanson, 391 1996; Grabowski et al., 2011).

392

393

3.2 Alluvial exchange in big rivers 
Whilst meandering/braiding discrimination on small streams can be attempted through power and sediment size (e.g., Van den Berg, 1995; Ferguson, 1997; Lewin and Brewer, 2001), such a range in controlling variables is less apparent for big rivers (Latrubesse, 2008; Kleinhans and Van den Berg, 2011), and it is thus less easy to account for their different patterns in such terms. In large rivers, some styles are maintained for hundreds of kilometres when developed at low gradients in sand and finer sediment (e.g., Congo River over 1200 km

402 from $0^{\circ} 45^{\prime} \mathrm{N}, 24^{\circ} 26^{\prime} \mathrm{E}$ to $\left.2^{\circ} 12^{\prime} \mathrm{S}, 16^{\circ} 15^{\prime} \mathrm{E}\right)$. Others have marked pattern changes, variable 403 sediment feed rates from tributaries and different forms of alluvial exchange with floodplain404 stored sediment. Minor gradient changes, often through local plate flexuring and faulting, can 405 have large effects on sedimentation at low slopes (Mertes and Dunne, 2007; Frings, 2008), 406 for example with silty levees prograding across ponded flows rather than sandy lateral 407 accretion at river banks.

408 Alluvial settings are dependent on mainstream and tributary inputs of water and sediment 409 as discussed in Section 2 (Figs 1A-B), but alluvial morphologies are essentially determined at 410 the reach scale. Sediments are not only transported through reaches (as suspended 411 sediment or as migrating bedforms), but are also subjected to transfer processes into and out 412 of alluvial storage. Figure 6 summarises the various forms of exchange that may take place. 413 These include deposition on the floodplain (a-e), exchanges involving main channels (f-i) and 414 deposition within them (h), or material input from tributaries (j). Whilst the size of channels 415 reflects formative water discharges, it is these sediment exchanges that generate outline 416 channel morphology - whether by bedform development into islands; by loss of load through 
417 bed aggradation or slackwater and levee deposition; through recycling by bank erosion and

418 active lateral accretion, or redirection by avulsion. If there is minimal exchange, even large

419 rivers may remain straight (e.g. The Niger for $25 \mathrm{~km}$ at $6^{\circ} 27^{\prime} \mathrm{N}, 6^{\circ} 40^{\prime} \mathrm{E}$, or the Yenisei for 200

$420 \mathrm{~km}$ from $63^{\circ} 43^{\prime} \mathrm{N}, 87^{\circ} 19^{\prime} \mathrm{E}$ to $\left.65^{\circ} 37^{\prime} \mathrm{N}, 88^{\circ} 03^{\prime} \mathrm{E}\right)$ though with the bed diversified by migrating

421 bedforms that are exposed at low flows. Table 1 presents summary characteristics for

422 selected individual reaches on the 20 largest rivers ranked by mean annual runoff. For some,

423 lateral exchange by bank erosion and accretion ( $f$ and $g$ in Fig. 6) dominates; others have 424 seemingly non-migrating channels with levees and floodbasins ( $a$, b, and e in Fig. 6); yet

425 others have floodplains blanketed with overbank sediments and infilled palaeochannels (c in

426 Fig. 6). To complicate matters further, within hydraulic floodplains (the area inundated in

427 major floods), large rivers can have genetically-decoupled sediment systems, with the largest

428 channel acting as a dominant or lesser participant for both water and sediment transfer or

429 deposition (e.g., the Amur at $49^{\circ} 36^{\prime} \mathrm{N}, 136^{\circ} 32^{\prime} \mathrm{E}$ ). If they are present, smaller but sediment-

430 rich tributaries (j) may dominate alluvial sedimentation. For example, the sediment-rich

431 Madeira provides half the sediment load of the main Amazon channel, and its larger and

432 coarser sediment load is associated with an increase in the number of islands and bank

433 erosion rates downstream of the junction (Mertes et al., 1996). In their absence, a major but

434 relatively sediment-poor river may only alluviate a narrow channel corridor, passing between

435 floodbasins where lakes are impounded (e.g., the Magdalena at $08^{\circ} 49^{\prime} \mathrm{N}, 74^{\circ} 22^{\prime} \mathrm{W}$, see Fig.

436 3B). The majority of big rivers have adjacent standing water bodies in a range of sizes and

437 which may be refilled during floods (Table 1, Figs 7A-B). None of the characteristics

438 described above are unique or exclusive to big rivers. The sediment exchanges illustrated in

439 Fig. 6 are common to all floodplain rivers - large and small. But big rivers are characterised 
440 more generally by a stronger decoupling from non-alluvial sediment input (i.e. more remote

441 from adjacent valley slopes and flowing over low-gradient surfaces) and a greater role played

442 by channelised flows in tributary or accessory channels for routing flow and sediment.

443 Given the range of sediment loadings available to trunk and tributary combinations, 444 including bed- and suspension- load, the variety both between but also within large-river 445 floodplains is considerable, even where there is a common valley-floor gradient and flood 446 level set by the major river. The sediment actually available for major rivers to use in 447 alluviating floodplains is as variable as the accommodation space provided, but can be high 448 where regular monsoon-flooding facilitates long periods of overbank flow. For example, 449 Allison et al. (1998) suggest between 31 and $71 \%$ of the total alluvial sediment budget may 450 be trapped landward of the Ganges-Brahmaputra mouth whilst Islam et al. (1999) estimate $45149 \%$ of the total load is deposited before the coastal region with $28 \%$ deposited on the 452 floodplain and $21 \%$ within the active channels. The proportion of sediment trapped within 453 large river catchments is not necessarily different to small rivers but the absolute volume of 454 sequestration is orders of magnitude greater (Fielding et al., in press). The volume 'extracted' 455 by overbank sedimentation can decrease significantly the downstream fining rate of large 456 sand-bed rivers (Frings, 2008) and during high-magnitude floods the volume of overbank 457 sedimentation can be of the same order as the sand input from upstream as observed by Ten 458 Brinke et al. (1998) for the lower River Rhine.

459 The different combinations of sedimentation type lead to floodplain morphologies for big 460 rivers that can be classified into four main types (Fig. 8, Table 1). The hydraulic and 461 sedimentation systems on big rivers can range from lacustrine-dominated (Type 1) through 462 mainstream-dominated (Type 2), to tributary or accessory stream dominated (Types 3(a)- 
463 (3b)), and finally to confined or bedrock-dominated (Type 4). As noted in Section 3.1, most 464 big river channel patterns are anabranching (Latrubesse, 2008) and individual branches can 465 have different functions and status. Where the channel divides, it is possible for inundated 466 floodplains to have functionally-separate accessory sedimentation systems operating within 467 them even without tributary participation (Fig. 8, Type 3(b)(i)). These accessory channels are 468 often characterised by relatively small-scale, laterally accreting point bars with levees. For 469 example, the Amur at $48^{\circ} 44^{\prime} \mathrm{N}, 135^{\circ} 16^{\prime} \mathrm{E}$ has an anabranching mainstream channel that 470 accommodates most flow and sediment transport, but also a system of smaller meandering 471 accessory channels that branch off into the floodplain siphoning off flood sediment and 472 discharge (Fig. 9). In large rivers, and unlike smaller rivers it can be this accessory system, 473 rather than the relatively straight bedload-transporting main channel, which dominates the 474 near-surface sedimentation and the morphology of the floodplain itself. Other examples of 475 accessory channels are along extended lengths on the Solimões-Amazon (e.g., $02^{\circ} 43^{\prime} \mathrm{S}, 64^{\circ}$ $47655^{\prime} \mathrm{W}$ ), the upper and middle Paraná (e.g., $27^{\circ} 14^{\prime} \mathrm{S}, 58^{\circ} 23^{\prime} \mathrm{W}$, see Fig. 8) and over $150 \mathrm{~km}$ 477 along the Upper $\mathrm{Ob}\left(\mathrm{e} . \mathrm{g} ., 55^{\circ} 53^{\prime} \mathrm{N}, 83^{\circ} 45^{\prime} \mathrm{E}\right)$ where reaches have relatively straight courses 478 with major migrating bedforms, but also a system of much smaller meandering accessory 479 channels on the floodplain (Latrubesse and Franzinelli, 2002; Iriondo et al., 2007; Rozo et al., 480 2012). Comparable features also occur on the Amazon (Mertes and Dunne, 2007), and have 481 been observed on the Lena in a permafrost environment (Costard and Gautier, 2007). 482 Accessory streams that branch off from the main channel can form large internal deltas if 483 they enter adjacent flood basins (Latrubesse et al., 2010). On a smaller scale, Rowland et al. 484 (2005), Day et al. (2008) and Constantine et al. (2010) have drawn attention to tie channels, 485 bi-directional channels connecting the main river to lakes and oxbows. On the Fly River in 
486 Papua New Guinea these play a major role in transferring fine sediment from channel to

487 floodbasins with about $40 \%$ of the total river sediment load being deposited overbank up to

$48810 \mathrm{~km}$ away from the floodplain channel (Day et al., 2008). On large rivers, the ability 489 differentially to distribute discharges and sediment loadings between two or more channel 490 systems, coupled with tributary diversity, gives their floodplain processes a functional and 491 intrinsic pluralism (Type 3, Fig. 8). This is not as common in smaller rivers (though see the 492 example of Magela Creek described by Jansen and Nanson, 2004).

493 Reach-scale research in recent years has shown that within-channel sediment transfer 494 processes in large rivers are more complicated than outline channel pattern might suggest 495 (Kocurek et al., 2010). For example, migrating bedforms that account for a major proportion 496 of bed sediment transfer in large rivers with predominantly sandy beds (Frings, 2008) pass 497 through channels causing local macro-turbulence such as fluid upwellings (Best, 2005; 498 Shugar et al., 2010) and possibly a disturbance and breakdown of channel-wide secondary 499 circulation (McLelland et al., 1999; Parsons et al., 2007). In large rivers, bedforms such as 500 dunes may respond very differently to an increase in stage so that the relationship between 501 dune height and flow depth may have considerable scatter (e.g. Julien and Klaassen, 1995; 502 Best et al., 2007), be very weak or non-existent (Leclair, 2011) or actually have an inverse 503 relation such that dunes decrease in height with greater flow depths (Amsler and Garcia, 504 1997). Relict dune topography from high flow stages may still have an influence on the 505 location and size of bedforms that occur at low stages as shown for the Mississippi by 506 Nittrouer et al. (2008), yet the interactions between bedforms themselves can give rise to a 507 self-organised pattern (Kocurek et al., 2010). 
508 Dune bedforms may be passive or active contributors to braid-bar initiation and growth

509 (Ashworth et al., 2000; Sambrook Smith et al. 2009) depending on the local flow and

510 sediment supply conditions and those inherited from immediately upstream. Large rivers

511 typically have channels with width-depth ratios in excess of 100 (Thorne et al., 1993; Xu,

512 2004; Latrubesse, 2008) that may result in a simple flow convergence and divergence around

513 and over bartops (Richardson and Thorne, 1998; McLelland et al., 1999), but paradoxically,

514 with few channel-wide unit bars migrating through the main thalwegs (Best et al., 2007;

515 Sandbach et al., 2010). Some large rivers bifurcate and remain divided for $100 \mathrm{~km}$ and more,

516 and some stay within a wide braidplain but experience extraordinarily high local rates of bank

517 erosion (up to $1 \mathrm{~km} \mathrm{yr}^{-1}$, cf. Best et al., 2007). The timescales over which large rivers migrate

518 and evolve vary considerably even for rivers with similar mean annual discharge and slope.

\section{4. Examples of contrasting large river channel pattern}

523 In order to appreciate the variability in big river channel pattern and processes, three

524 examples will now be considered covering a spectrum of channel styles.

525

5264.1 The River Ob

528 The River Ob has a catchment area $\sim 2.77 \times 10^{6} \mathrm{~km}^{2}$, a mean annual discharge $\sim 400 \mathrm{X}$ $52910^{9} \mathrm{~m}^{3}$ with ice-bound winters for reaches north of Barnaul $\left(53^{\circ} 21^{\prime} \mathrm{N}, 83^{\circ} 48^{\prime} \mathrm{E}\right)$, and is 530 characterised by a relatively low suspended sediment yield that decreases significantly 
531 downstream as discharge increases (Bobrovitskaya et al., 1996; Meade et al., 2000).

532 Upstream of the Irtysh junction at Khanty-Mansiysk (Fig. 10A) sediment yields over several

533 decades have been less than $20 \times 10^{6}$ tonnes $\mathrm{yr}^{-1}$. Since 1957 , flow has been partially

534 regulated by the Novosibirsk Reservoir (Fig. 10A). In recent decades, and in different parts of

535 the system, there has been a decrease in summer flows because of irrigation, and greater

536 winter flows released during power generation, but there have also been precipitation

537 changes (Yang et al., 2004). From a geomorphological point of view the flow regime remains

538 dominated by high-magnitude annual snowmelt floods that peak in May and June.

539 Below Krivosheino (Fig. 10A; elevation $\sim 82 \mathrm{~m}$ ) and as far as Belogor'ye (Fig. 10A;

540 elevation $\sim 24 \mathrm{~m}$ ), the river flows for some $1000 \mathrm{~km}$ within a broad floodplain some $8-25 \mathrm{~km}$

541 wide. Valley gradients are low, generally below $0.1 \mathrm{~m} \mathrm{~km}^{-1}$ and almost imperceptible for long

542 distances. Nevertheless the valley floor itself is characterised throughout by remarkable

543 meandering channel-trace patterns with sinuous sets of scrolls and palaeochannels (Fig.

544 10B). These meanders have long attracted scientific attention, some reported in English

545 language publications (e.g., Kondrat'yev and Popov, 1967; Kondrat'yev, 1968; Kulemina,

546 1973; Alabyan and Chalov, 1998). Meandering style involves simple loops with circular arcs

547 and moderate sinuosity without developing low-radius bends or omega shapes. Compound

548 loops are virtually absent, probably due in part to early-stage cutoffs and in part to a relative

549 lack of point bar forcing/pushing (Parker et al., 2011; see further discussion later). Floodplain

550 ridge and swale patterns suggest that radial expansion of loops has dominated.

551 Emergent mid-channel bars are located sporadically and rarely in the main channels,

552 and, by comparison with channel width (c. 0.5-1.0 km) and meander arc length, many are

553 relatively small in size (e.g., 2 by $0.6 \mathrm{~km}$ ). Satellite imagery covering the period September 
5541989 to October 2010 near Krivosheino (Fig. 10B) shows mid-channel bars to be mostly

555 transverse-symmetrical forms that wrap around vegetated islands, and deposit at channel 556 junctions. Mean migration rate of the mid-channel bars at Krivosheino is $30 \mathrm{~m} \mathrm{yr}^{-1}$.

557 Emergent bars can have a corrugated appearance or barbed planform as a result of 558 dune stacking (Bridge, 1993; 2003). Following bar stabilisation and growth, islands may be 559 trimmed by bounding channels into hydrodynamic shapes, with pointed ends and elongate 560 curving outlines (e.g., $61^{\circ} 04^{\prime} \mathrm{N}, 75^{\circ} 28^{\prime} \mathrm{E}$ ). By contrast, in bank-attached locations, 561 sedimentation may be in the form of narrow but much extended linear or lunate scrolls 562 relating to loop expansion (e.g., $59^{\circ} 24^{\prime} \mathrm{N}, 80^{\circ} 02^{\prime} \mathrm{E}$ ). These may assimilate sets of dunes and 563 have shorter and wider stalled bars attached to them (Fig. 10B). Vegetation changes show a 564 degree of mid-channel bar stabilisation, but much more dominant on the floodplain surface 565 are the sets of ridges and swales marking point bar growth (Figs 10B and C).

566 Secondary channels are prominent across the valley floor. On main channels, there are 567 cutoff chutes producing what Kulemina (1973) called 'incomplete meandering' (e.g., $61^{\circ} 03^{\prime} \mathrm{N}$, $\left.56875^{\circ} 48^{\prime} \mathrm{E}\right)$ such that loop development becomes divided before the highest sinuosities are 569 reached (cf. Mertes et al., 1996). Large point bar complexes may be bisected in this way to 570 produce islands of asymmetric planform with a concave (inner) and a convex (outer) bank 571 (e.g., $58^{\circ} 24^{\prime} \mathrm{N}, 82^{\circ} 27^{\prime} \mathrm{E}$ ). Chute channels may be actively modified into shorter-wavelength 572 meanders. There is also larger-scale anabranching in which separate meandering courses 573 can run for many kilometres, for as much as $400 \mathrm{~km}$ at and below Surgut (Fig. 10A, see 574 image in Fig. 10D). The long islands created by these chute channels may be lozenge575 shaped or 'beaded' in appearance, widening or narrowing in relation to the independent and 576 actively meandering bounding channels (Fig. 10D, also see the Amur at $52^{\circ} 00^{\prime} \mathrm{N}, 140^{\circ} 15^{\prime} \mathrm{E}$ ). 
577 This form of anabranching is different from that often associated with successful avulsion

578 from an aggrading channel or narrow channel belt into a lower elevation floodplain or

579 floodbasin (Makaske, 2001; Jerolmack and Mohrig, 2007; Makaske et al., 2009). On the Ob,

580 laterally-mobile rivers occupy the whole valley floor, there are no striking channel-to-

581 floodplain elevation differences arising through aggradation, and division is triggered during

582 the meandering process. Avulsion is facilitated not so much by raising the channel or channel

583 belt, but more likely by flood spillage via local bank lowering along the line of palaeochannels

584 and swales (cf. Fig. 10D). In responding to topographic control, the meandering Ob follows

585 one of the several avulsion mechanisms described for braided streams in which switching is

586 guided by relict floodplain relief (Leddy et al., 1993; Warburton et al., 1993).

587 In addition to main channel branches, there are numerous smaller, meandering tributary

588 and accessory channels with shorter meander wavelengths and associated scroll patterns

589 (Figs 10C and D). Tributaries may have high sinuosities, with their own numerous cutoffs and

590 bend dimensions scaling with channel size, but in the main valley some are guided along

591 larger palaeochannel arcs derived from the main river or its branches. All of these channels

592 are picked out by standing water in point bar swales (labelled 1 in Fig. 10C), in arcuate dead

593 channel loops (labelled 2 in Fig. 10C), and in occasional broader unsedimented water bodies

594 (labelled 3 in Fig. 10C). Older parts of the floodplain, and areas beyond the shallow valley

595 floor, have circular thaw ponds and thermokarst features (labelled 4 in Fig. 10C).

596 Repeat imagery suggests moderate rates of morphological change. Fig. 10C shows

597 scrolls on a developing loop near Ust'-Tym (location in Fig. 10A). Comparison of imagery

598 between October 1972 and September 2010 shows a maximum of $450 \mathrm{~m}$ of scroll bar

599 advance over the 38 year period $\left(12 \mathrm{~m} \mathrm{yr}^{-1}\right)$. This compares to rates of bank erosion on the 
$600 \mathrm{Ob}$ (measured off maps from 1897-1958) of $0-15 \mathrm{~m} \mathrm{yr}^{-1}$ although displacements of a

601 kilometre or more have been measured for certain sites (Kulemina, 1973).

602 Even at this maximum rate, the point bar complex at Ust'-Tym would have taken three to 603 four centuries to develop, and perhaps rather longer. In this situation, individual scrolls 604 develop in a spit-like manner as bars accrete following bank erosion on the opposite side of

605 the channel. Growth of detached ridges is terminated repeatedly as a new growth point 606 develops upstream, and a large digitate area of slackwater has formed and remained 607 unsedimented in the counterpoint zone at the downstream end of the point bar complex. The 608 meander evolution is dominated by local bank-to-bar sediment exchange of matching volume 609 (Neill, 1987). The low suspended-sediment supply that characterises the present-day Ob 610 leaves abandoned channel voids as open water variously connected or detached from 611 mainstream low-water channels.

612 There has been long-running interest in the seemingly paradoxical significance either of 613 eroding bends or of depositing bars in 'forcing' channel change, particularly involving bar-

614 bend theory (e.g., Blondeaux and Seminara, 1985; Ikeda and Parker, 1989). It is the dynamic

615 flow fields that interact with particle entrainment or deposition to produce feed-back 616 morphological effects, and both types of forcing may happen. Bars may be regarded as 'free' 617 where they migrate quasi-independently, or 'forced' if they follow changing bend topography 618 as growing point bars. In much the same way, Lucci et al. (2010) contrast island formation by 619 'width forcing' and 'curvature forcing', whilst Parker et al. (2011) describe 'bank pull' and 'bar 620 push' processes in meanders. On the Ob, it appears that floodplain-dominating elongate 621 point bar scrolls follow bank-arc recession and in gross terms are width-forced. Other bars 622 are more likely related to sediment stalling in width-permitting reaches (both at divergence 
623 points and in straighter but relatively wide channels). These only rarely appear to force bank

624 changes to produce small-scale bank 'bites' related to mobile/stalled bar dimensions rather

625 than longer meander-scale arcs (cf. Lewin, 1976).

626 Below the junction of the Ob with the Irtysh at Khanty-Mansiysk (location in Fig. 10A), at 627 an of elevation $80 \mathrm{~m}$, the river runs for a further $650 \mathrm{~km}$ in a broad trough (15-50 km wide) 628 with numerous levee-lined channels running between often-flooded wetlands. Some 629 channels are meandering and show some evidence of past lateral migration, but the main 630 channel can be near-straight and lined by straighter levees and scrolls showing small-scale 631 alignment oscillations. In places (e.g., $63^{\circ} 41^{\prime} \mathrm{N}, 65^{\circ} 32^{\prime} \mathrm{E}$ ) the main channel divides into four 632 or five meandering ones. Open water occupies the lower ends of tributaries to this partially 633 infilled ria. Upstream of Khanty-Mansiysk, both the Ob and the Irtysh have floodplains 634 dominated by laterally migrating channels, and their junction marks a change to levee and 635 backswamp-dominated sedimentation developed in the finer sediments available here. The 636 river junction appears to coincide with a transition from sand to silt/clay dominance (cf. 637 Latrubesse and Franzinelli, 2005).

638 In summary, mobile barforms and islands diversify meander morphology along the 639 middle Ob, but it appears that elongate meander scrolls have much greater long-term 640 preservation potential in association with planform evolution. Scrolls are temporally and 641 spatially lagged outcomes relating to bank erosion. Scrolls temporally follow channel 642 widening in association with erosion on the opposite bank, and spatially respond as material 643 is received from upstream bank recession. These scrolls are especially visible and 644 prominent, compared to some examples on smaller rivers (e.g. Nanson, 1980), because they 645 are relatively unmasked by overbank fine sediment deposition, have little mature vegetation, 
646 and unfilled curving palaeochannels and elongate and digitate depressions between scrolls

647 dominate.

648 Four types of anabranching occur on the Ob: (i) small islands generated from stabilised

649 bars in-channel; (ii) islands with asymmetrical convex-concave outlines within larger meander

650 bends resulting from cutoff activity; (iii) longer beaded and lozenge forms that have

651 independently-generated multi-bend meandering outlines, and which may extend for tens to

652 hundreds of kilometres; and (iv) small and often tortuous floodplain drainages often

653 connecting larger palaeoforms to main channels.

654 Channel patterns on the Ob may be interpreted as the product of lateral meander mobility 655 and sediment reworking under conditions of low sediment input. Downstream of Khanty656 Mansiysk (Fig. 10A) there is a change in style involving levees and floodbasins. The 657 persistence of multiple open channels, only some of which actively transmit sediment, 658 appears to relate to sediment starvation, probably during the Holocene, Floodplain relief is 659 therefore left open for ponding and drainage, and exposed to ongoing avulsion-breaching 660 and reactivation where there is active channel shifting.

\subsection{The Jamuna River}

The Jamuna is the local name given to the Brahmaputra River for the $240 \mathrm{~km}$ reach that 665 flows in Bangladesh from the northern border $\left(25^{\circ} 48^{\prime} \mathrm{N}, 89^{\circ} 50^{\prime} \mathrm{E}\right)$ down to the junction with 666 the Ganges $\left(23^{\circ} 48^{\prime} \mathrm{N}, 89^{\circ} 46^{\prime} \mathrm{E}\right.$, see Fig. 11). The Jamuna has one principal tributary, the 667 Teesta River in the north-west (Fig. 11) and two major offtakes on the left bank that are the 668 Old Brahmaputra (abandoned in the mid-19 ${ }^{\text {th }}$ century, see Bristow, 1999) and the 
669 Dhaleshwari (Fig. 11). The Jamuna is one of the most active braided rivers in the world with a

670 braidplain up to $15 \mathrm{~km}$-wide in flood, scour depths up to $40 \mathrm{~m}$ and bank erosion rates on

671 average approximately $50 \mathrm{~m} \mathrm{yr}^{-1}$, but up to $1 \mathrm{~km} \mathrm{yr}^{-1}$ on main channel outer bends (Klaassen

672 and Vermeer, 1988; ISPAN, 1993; Flood Action Plan 24 1996a; Best and Ashworth, 1997;

673 Khan and Islam, 2003; Best et al., 2007). At Bahadurabad (Fig. 11) the mean annual

674 discharge is $20200 \mathrm{~m}^{3} \mathrm{~s}^{-1}$. This varies from a minimum of $\sim 2800 \mathrm{~m}^{3} \mathrm{~s}^{-1}$ to a peak of $\sim 100000$

$675 \mathrm{~m}^{3} \mathrm{~s}^{-1}$ as experienced in both the 1988 and 1998 floods (EGIS, 1997; Chowdhury, 2000). The

676 annual hydrograph has a stage change of $\sim 6 \mathrm{~m}$ (Sarker and Thorne, 2006; their figure 2, p.

677 291) due to monsoonal rainfall with low flow mainly in February/March and peak flows in 678 July/August. Mean water slope is 0.000076 over the first $130 \mathrm{~km}$ and 0.000065 further 679 downstream (Flood Action Plan 24, 1996b). The grain size of the Jamuna is mainly fine sand 680 and silt with less than 1\% clay (FAP24, 1996b) and an average grain size of $220 \mu \mathrm{m}$ (Barua, 681 1994; Sarker and Thorne, 2006). The fine and abundant sediment supply together with high 682 water discharges results in the one of world's highest sediment yields that is estimated at 683 between 590 and $792 \mathrm{Mt} \mathrm{yr}^{-1}$ (FAP24, 1996a; Islam et al., 1999) with up to 10\% transported 684 as bedload (Klaassen et al., 1988).

685 The Jamuna is predominantly a braided river characterised by divided flow and strongly 686 stage-dependent bars that are unconsolidated, dynamic, poorly vegetated and overtopped at 687 flows less than bankfull. Some parts of the Jamuna have been described as anastomosing 688 (cf. Bridge, 2003, his fig. 5.5; Sarker and Thorne, 2006, their figure 14) whereby multiple689 channels with vegetated islands or stable alluvial islands divide flow up to bankfull and typical 690 width of the channels is much smaller than that of the bars (Nanson and Gibling, 2004). 691 Paradoxically, when slope is plotted against bankfull discharge on the classic channel pattern 
692 discrimination diagram of Leopold and Wolman (1957), the Jamuna plots in the meandering

693 field, suggesting the controls on channel planform are more complex than solely slope and

694 discharge (Sarker and Thorne, 2006). The Jamuna is an example of an anabranching river

695 (Nanson and Knighton, 1996) with braided and occasional anastomosing branches that

696 divide around vegetated, stable alluvial islands with heights up to the adjacent floodplain

697 (Best and Ashworth, 2007).

698 Analysis of historical maps and recent satellite images of the Jamuna show that there has

699 been a progressive widening of the braidbelt by $\sim 50 \mathrm{~m} \mathrm{yr}^{-1}$ over the period 1834-1992 (Flood

700 Action Plan24, 1996a) although the rate of widening has decreased more recently to $\sim 30 \mathrm{~m}$

$701 \mathrm{yr}^{-1}$ between 1992 and 2000 (Sarker and Thorne, 2006). Part of the reason for the increase in

702 braidbelt width is attributed to the westward migration of the main channels due to uplift of the

703 Madhupur Tract Pleistocene sediment (location in Fig. 11) (Coleman, 1969; Thorne et al., 704 1993; Khan and Islam, 2003), although periods of eastward migration of the braidbelt have 705 also been recorded (EGIS, 1997). Sarker and Thorne (2006) also note that local increases in 706 braidbelt width may be related to the propagation downstream of a sediment pulse generated

707 by the 1950 Richter magnitude 8.6 earthquake in Assam. Localised, high rates of bank 708 erosion are associated with the downstream migration of individual channel bends that abut 709 the weak, non-cohesive floodplain banks that are undercut and experience large-scale slab 710 failure (Thorne et al., 1993; Best et al., their fig. 19.25, p. 423).

711 Unlike the Ob (Section 4.1) and Paraná (Section 4.3), the floodplain of the Jamuna is

712 decoupled from the main channel for most of the year (cf. Lewin and Ashworth, in press) 713 except during peak monsoonal floods. Extensive wetlands or clusters of water bodies are 714 absent (see Fig. 11). Floodplain relief is relatively modest and associated with (i) abandoned 
715 bars, scrolls and dunes (relief up to $2 \mathrm{~m}$ ), (ii) river levees alongside active main channels

716 (relief up to $3 \mathrm{~m}$ ), (iii) crevasse splays caused by breaches of natural and human-made

717 levees, and (iv) flood basins or enclosed depressions between the levees of adjacent

718 channels that usually drain on the falling stage, although some permanent water bodies can

719 contain peat accumulations (ISPAN, 1995).

720 Sediment transport of bed material in the Jamuna is predominantly as sand dunes that 721 migrate at all flow stages in the main channels (Roden, 1998; Best et al., 2007, their fig. 19.7, 722 p. 407). Dune heights range from 0.1 to $6 \mathrm{~m}$ (Julien and Klaassen, 1995; Roden, 1998) and 723 with a low leeside angle (generally $<10^{\circ}$ ) suggesting flow separation in the dune leeside is 724 absent or intermittent as has been demonstrated for other large rivers (e.g. Smith and 725 McLean, 1977; Kostaschuk and Villard, 1996; Ten Brinke et al., 1999; Shugar et al., 2010). 726 The majority of flows in the Jamuna generate bedforms within the dune stability field and 727 upper-stage bedforms are rare except in shallow flows on bar-tops (Bristow, 1993; Julien and 728 Klaassen, 1995).

729 Since dunes are ubiquitous in the Jamuna, they are also responsible for the creation and 730 growth of sand bars from 100s metres to several kilometres in length (Figs 11 and 12). Two 731 scales of bars exist in the Jamuna: (i) 'compound bars' (Fig. 12B, labelled 2) that scale with 732 local channel width and mean flow depth, and (ii) 'vegetated islands' (Fig. 12B, labelled 3)

733 that are stable, older, bar complexes with heights up to the adjacent floodplain (Thorne et al., 734 1993; Ashworth et al., 2000). Compound bars in the Jamuna are predominantly composed 735 internally of stacked 2D and 3D dunes although bar-margin slipface accretion is also present 736 at barheads and at obliquely migrating bar edges (Bristow, 1993; Best et al., 2003, their fig. $737 \quad 5$, pp. 522-523). 
738 Migrating unit bars that are discrete, solitary barforms with a lobate planform (Bridge, 739 1993) are rare in the Jamuna (Fig. 12B, labelled 1), which is different from observations in 740 smaller sand-bed rivers (e.g. Smith, 1971; Sambrook Smith et al., 2006). Unit bars are not 741 prevalent as exposed bedforms either at low flow in the main or secondary channels (Figs. 742 12A-B and D), or in the subsurface (Best et al., 2003). It is unclear why unit bars, that are the

743 fundamental building block in small sand-bed rivers (Sambrook Smith et al. 2006), are not 744 common in large rivers (see the same observation for the Rio Paraná in Section 4.3). One 745 reason may be that the potential for unit bar initiation and channel-wide extension is reduced 746 due to the suppression or absence of significant channel-wide secondary flows as observed 747 in large rivers with high width-depth ratio channels (McLelland et al., 1999; Parsons et al., 748 2007).

749 Bar types in the Jamuna are commonly mid-channel, longitudinal forms (Figs 12A-D) with 750 sharp, erosional margins (Fig. 12D) indicative of the high degree of reworking and bar 751 trimming. Mid-channel bars maintain their rhomboidal planform shapes at high flow (Fig. 12C) 752 rather than becoming heavily dissected with cross-channels of different orders. Mid-channel 753 bars enlarge both up-, down- and across-stream by either adding dunes that stall and stack 754 at the bar margins (Best et al., 2003), or through lateral accretion by addition of successive 755 individual scroll bars (Bristow, 1987). Migration rates for small ( $<4 \mathrm{~km}$ long), unvegetated 756 compound bars are extremely high at up to $3 \mathrm{~km} \mathrm{yr}^{-1}$, but larger compound bars (up to $10 \mathrm{~km}$ 757 long) move more slowly at up to $1 \mathrm{~km} \mathrm{yr}^{-1}$ usually through progressive barhead reworking and 758 bartail accretion (cf. Best et al., 2007; their figs 19.26b-h, p. 425). The rapid rates of bar 759 migration, bank erosion and channel change mean that the entire planform of the active parts 760 of the Jamuna braidbelt (usually up to $5 \mathrm{~km}$-wide) is reworked over a decadal time-scale 
761 (compare Figs 12A-D) and km-long bars are created, migrate and are then destroyed in

762 under five years (Ashworth et al., 2000; Best et al., 2007). Only the vegetated and higher

763 'islands' are stable for more than decades often because the main channel has avulsed or

764 migrated over to another part of the braidplain. The Jamuna represents one of the world's 765 most dynamic large rivers with ephemeral bars, a shifting braidbelt and a planform that is

766 continually changing.

767

4.3 The Rio Paraná

769

770 The Río Paraná has a drainage basin of $2.6 \times 10^{6} \mathrm{~km}^{2}$ that covers the surface of four

771 countries in South America (Latrubesse et al., 2005; Iriondo, 2007). The 3965 km-long

772 Paraná is divided conventionally into three reaches termed the Upper Reach (source to the

773 junction with the Rio Paraguay near Corrientes), Middle Reach (down to Diamante) and

774 Lower Reach (to the mouth) (locations in Fig. 13A, see Orfeo and Stevaux, 2002; Ramonell

775 et al., 2002; Iriondo, 2007). The discussion herein concentrates on parts of the Upper and

776 Middle reaches from Itati $\left(27^{\circ} 16^{\prime} \mathrm{S}, 58^{\circ} 14^{\prime} \mathrm{W}\right)$ to Santa Fe $\left(31^{\circ} 38\right.$ 'S, $\left.60^{\circ} 42^{\prime} \mathrm{W}\right)(\mathrm{Fig} .13 \mathrm{~A})$.

777 Mean annual water discharge of the Paraná at Itati is $-12,000 \mathrm{~m}^{3} \mathrm{~s}^{-1}$, increasing to $778 \sim 17,000 \mathrm{~m}^{3} \mathrm{~s}^{-1}$ at Corrientes, $30 \mathrm{~km}$ downstream of the Río Paraguay tributary (Orfeo and 779 Stevaux, 2002). Maximum discharge measured on the Paraná in the last century is 780 associated with an El Niño-driven large flood in 1983 that peaked at $33,740 \mathrm{~m}^{3} \mathrm{~s}^{-1}$ in the

781 Upper Reach (Orfeo and Stevaux, 2002) and 55,000 $\mathrm{m}^{3} \mathrm{~s}^{-1}$ in the Middle Reach (Amsler and 782 Garcia, 1997). Mean bed slope near Corrientes ranges from 0.000049 (bankfull water surface 783 slope; Latrubesse, 2008) to 0.000085 (channel slope; Orfeo and Stevaux, 2003). Mean 
784 annual sediment discharge of the Paraná increases dramatically from $\sim 19$ to $\sim 158 \times 10^{6} \mathrm{t} \mathrm{yr}^{-1}$ 785 at the junction with the Río Paraguay, primarily due to the large input of suspended sediment

786 from the Paraguay-Bermejo tributary system (Lane et al., 2008; Amsler and Drago, 2009).

787 Between 80 and $91 \%$ of the sediment load in the Middle Reach of the Paraná is silt and clay 788 washload (Amsler et al., 2007; Amsler and Drago, 2009). Bed material of the Upper and 789 Middle Reaches of the Río Paraná is well sorted, predominantly medium-to-fine sand 790 although some fine gravel is present in the channel thalweg (Santos and Stevaux, 2000;

791 Amsler et al., 2007).

792 Except at the junction with the Rio Paraguay (Fig. 13A), the outline planform of the Upper 793 and Middle Reaches of the Paraná is relatively straight (sinuosity less than 1.3; Amsler et al., 794 2005), but with downstream alternations between 2-3 km wide 'enlargements' that are 795 characterised by two or more main channels with mean depths of 5-8 m, and 0.6-1.2 km796 wide, and well-defined, structurally-controlled constrictions with mean depths of $15-25 \mathrm{~m}$ that 797 are generally stable and have not migrated for the last 80 years (Amsler et al., 2005; Iriondo, 798 2007). The channel planform of the Paraná can be described as anabranching because it 799 contains multiple-channels that contain stable vegetated bars that divide flow up to bankfull 800 (Nanson and Knighton, 1996; Latrubesse, 2008). However, the division of discharge around 801 the km-scale bars is rarely even and usually one anabranch is dominant (Parsons et al., 802 2007; Szupiany et al., 2009; Sandbach et al., 2010).

803 The Rio Paraná bed is dominated by dunes at all flow stages (Parsons et al., 2005; 804 Kostaschuk et al., 2009; Shugar et al., 2010). Mean dune height and lengths of 1.5 and $6.4 \mathrm{~m}$ 805 respectively have been measured at low flow $\left(\sim 11000 \mathrm{~m}^{3} \mathrm{~s}^{-1}\right)$ near Corrientes with 806 superimposed dune heights and lengths of $0.3 \mathrm{~m}$ and $10 \mathrm{~m}$ (Parsons et al., 2005; Sambrook 
807 Smith et al., 2009). However, much larger dunes have been observed during floods in the

808 Paraná with heights up to $6.5 \mathrm{~m}$ and lengths of $320 \mathrm{~m}$ during the historic large flood in 1983

809 (Amsler and Garcia, 1997). Dunes in the Paraná, and in other large sand-bed rivers such as

810 branches of the Rhine and the Mississippi, may respond differently to rising flow stage

811 compared to smaller rivers (Garcia, 2008). Small dunes grow readily as discharge increases

812 but large dunes have been observed to do the opposite (Amsler and Garcia, 1997; their fig.

813 9, p. 583). Large dunes (> $1 \mathrm{~m}$ in height) may flatten and develop much lower leeside angles

814 during peak discharges possibly in response to an increase in suspended load, although

815 large dunes probably do not reach upper-regime plane bed during major floods (Julien and

816 Klaassen, 1997) Dunes therefore represent significant bed roughness in large rivers and

817 cause disruption to the near-bed flow structure (Parsons et al., 2005; Shugar et al., 2010)

818 that may have a significant effect on flow routing and the development of secondary flow

819 circulation (Parsons et al., 2007; Sandbach et al., in press).

820 Similar to the Jamuna, sand bar deposits in the Upper and Middle Paraná are dominated

821 by stacked 2D and 3D dunes together with high- and low-angle bar margin accretion

822 surfaces. Also similar to the Jamuna, bathymetric surveys on the Paraná reveal no

823 conclusive evidence for the prevalence or even presence of migrating unit bars through the

824 main channels (e.g., Shugar et al., 2010, their fig. 3, p. 259) even at major channel junctions

825 such as the convergence of the Paraguay and Paraná (Lane et al., 2008; their fig. 2, p. 5).

826 Four features characterise the Paraná planform morphology. Firstly, within the near827 straight channel outline, a dominantly sinuous meandering thalweg, up to $2 \mathrm{~km}$ wide and 26

$828 \mathrm{~m}$ deep at outer bank scours, with a wavelength of $\sim 12 \mathrm{~km}$ (Sandbach et al., 2010, their fig.

829 1, p. 410). This thalweg can convey up to $70 \%$ of the discharge and controls the direction of 
830 primary flow in most reaches with only localised curvature-driven secondary flow circulation

831 (Sandbach et al., 2010; Nicholas et al., in press). The dominance of a well-defined sinuous

832 thalweg means the Paraná is essentially a meandering main-stem trapped within an

833 anabranching channel-belt. Enlargement and downstream migration of the sinuous thalweg is

834 responsible for the majority of bankline change with maximum bank retreat rates of $100 \mathrm{~m} \mathrm{yr}^{-1}$

835 (Ramonell et al., 2002), but major avulsion over century time-scales is absent.

836 A second feature is a partially-coupled main and accessory channel system (see Fig. 8C).

837 North of Itati (Fig. 13A), the accessory channels probably owe their origin to former channel 838 belts of a Quaternary alluvial megafan that radiated out from $\sim 200 \mathrm{~km}$ upstream of the 839 Paraguay-Paraná junction (Iriondo, 2007; his figure 2.2, p. 35). These accessory channels

840 are highly sinuous and at locations (e.g., at $27^{\circ} 15^{\prime} \mathrm{S}, 58^{\circ} 27^{\prime} \mathrm{W}$ ) are close to eroding through 841 the intervening floodplain material and avulsing into the main Paraná channel. Some 842 accessory channels are major offtakes (e.g. the $49 \mathrm{~km}$-long Colastine and the $45 \mathrm{~km}$-long 843 offtake at Puerto Reconquista, locations in Figs 13B-C) and are rivers in their own right, 844 conveying discharges up to $1400 \mathrm{~m}^{3} \mathrm{~s}^{-1}$ and experiencing lateral bank erosion of several 845 metres per year (Iriondo, 2007).

846 A third feature of the Paraná is having few exposed sand bars, particularly in the Middle 847 Reach. Sand bars are typically bank-attached, transverse or medial bars (Santos and 848 Stevaux, 2000) with low-flow, mean geometries of $\sim 0.6( \pm 0.4) \mathrm{km}$ in length and $0.3( \pm 0.2) \mathrm{km}$ 849 in width. Drago (2010) measured the prevalence of different sand bar types in a $1087 \mathrm{~km}$ 850 reach downstream of the Yacyretá Dam $\left(27^{\circ} 29^{\prime} \mathrm{S}, 56^{\circ} 44^{\prime} \mathrm{W}\right)$ and noted accumulations of 851 sand onto the barheads of km-scale vegetated bars accounted for up to $77 \%$ of all sand bar 852 types. Drago's work showed a strong positive correlation between the number of sandy 
853 barheads and distance downstream which he suggested may be attributed to the higher ratio

854 of suspended-to-bedload downstream and therefore access to a source of more sandy

855 material. Isolated, sandy, non-vegetated bars are surprisingly rare in the main channel

856 between Itati and Santa Fe. Figure 14 shows decadal years of channel change and bar

857 development at the downstream end of the Middle Reach of the Paraná. Although a new,

858 2.5-km long, mid-channel bar developed in the mid-1980s (Figs 14 and 15), probably in

859 response to upstream scour and subsequent bank erosion during the large 1983 flood, the

$86040-\mathrm{km}$ reach shown in Fig. 14 is characterised by the lack and slowness of channel change.

861 Whilst the internal morphology of the new mid-channel bar is complex and suggests several

862 phases of aggradation and scroll bar addition (Fig. 15), the overall planform is relatively

863 simple and predictable (Fig. 14). Indeed, if the development of the same reach shown in Fig.

86414 is extended over longer time-scales using historic bathymetric surveys (Fig. 16), the

865 morphological change is characterised by a slowly migrating, sinuous thalweg that sweeps

866 across the channel-belt rather than rapid rates of bank retreat, bar reworking and local

867 avulsion as seen in the Jamuna (compare to Fig. 12). In the Paraná, heavily vegetated bars,

868 up to $15 \mathrm{~km}$-long, but more typically 5-8 km-long, fix and control the local channel

869 morphology. Sand bars are incidental, ephemeral depositional elements that wrap onto and

870 around these stable islands. The fully vegetated, stable islands are probably 100 s to 1000 s of

871 years old and are only completely overtopped in low recurrence-interval, major overbank

872 floods (e.g. $\sim 27000 \mathrm{~m}^{3} \mathrm{~s}^{-1}$ at Itati in January 2010).

873 Finally, a fourth feature of the Paraná morphology is the presence of extensive lotic

874 (flowing water) and lentic (still water) ecosystems that are eroded, filled or enlarged in each

875 flood event (Paira and Drago, 2006; 2007). Water bodies are linked ultimately to the short 
876 and long-term main river channel dynamics and are associated with (a) secondary channels 877 and ridge and swale topography in or immediately adjacent to the main channels, but also (b)

878 up to $28 \mathrm{~km}$ away where the floodplain develops to the margin of the alluvial valley (e.g. Fig.

879 7A) and water accumulates in depressions associated with older channel scars and zones 880 that are affected by neotectonic uplift and subsidence (Paira and Drago, 2007). Average lake 881 length, width and depth is $\sim 1.1 \mathrm{~km}, 0.4 \mathrm{~km}$ and $1.6 \mathrm{~m}$ respectively (1500 lakes measured in 882 the Middle Paraná; Paira and Drago, 2007). Nearly 25\% of the Middle Paraná floodplain 883 lakes have $5 \%$ of their surfaces covered with free or rooted macrophytes although the 884 coverage of aquatic vegetation ranges from 0 to $100 \%$ in lakes with areas less than $2 \mathrm{~km}^{2}$ 885 (Paira and Drago, 2006). Water bodies are therefore important carbon sinks and large 886 portions of the thick organic matter on their beds can be completely excavated during large 887 floods (Drago et al., 2003).

888 by catchment area, runoff or, in the case of the Jamuna and Paraná, sediment yield (Figs 1A893 B, Table 1). Like most big rivers all three rivers are anabranching, not only divided, but also 894 with a plural mixing of styles with accessory and tributary floodplain channels (Figs 8C, and 895 13B-C). They all have low valley gradients (generally $<1 \mathrm{~m} \mathrm{~km}^{-1}$ ), main-channel sandy bed 896 sediments, and variable suspended sediment loadings. Latrubesse (2008) suggests that low 897 specific stream powers of $<25 \mathrm{~W} \mathrm{~m}^{-2}$ are characteristic of large ('mega') rivers. However, 
898 such common properties are associated with different morphologies on the Ob, Jamuna and

899 Paraná and anabranching in each, is in practice, achieved in different ways.

900 In a spectrum of mainstream channel styles (Table 1, Figs 3 and 8), the Paraná is 901 virtually straight in outline with a sinuous thalweg, the Ob meanders and the Jamuna braids.

902 Sediment transfer styles differ considerably between the three rivers. In terms of the

903 classification introduced in Fig. 6 and Table 1, the Ob is (d,f,g,j)-dominant, the Jamuna 904 (f,g,h,i)-dominant, and the Paraná is a $(\mathrm{c}, \mathrm{d}, \mathrm{e}, \mathrm{h})$ mixture. They are contrasted in terms of bed 905 material in-channel transfers, channel shift rate and lateral floodplain exchange, and the 906 extent to which activity beyond the main channel controls valley floor morphology. Mean 907 rates of bank erosion and bar migration for the three rivers are orders of magnitude apart with 908 the Jamuna reworking its entire active braidplain every 10 years but the Ob and Paraná 909 taking decades-to-centuries to build individual bars. The Jamuna has few permanent

910 floodplain water bodies yet lotic and lentic ecosystems are an integral part of the channel 911 pattern and functioning of the Ob and Paraná. Clearly, some of the inter-river variability in

912 channel pattern is explained by regional and local controls such as climate, neotectonics and

913 regolith/erosion potential, but it is the variable sediment feeds and a range of in-channel and 914 channel-to-floodplain sediment exchanges that give each large river its unique style.

\section{5. Large and small river channel pattern}

919 The world's largest rivers differ from their monotonic smaller counterparts because they 920 have greater complexity introduced by crossing a series of chains of interlinked domains with 
921 contrasting fluvial functions (Section 2, see Fig. 2). Large rivers do not have a simple down-

922 valley trend in controlling variables (e.g., discharge, slope, grain size) as experienced in small

923 river catchments, nor do they have the associated downstream progression in channel

924 pattern (Church and Jones, 1982; their fig. 11.8, p. 303). Large rivers are highly-refined

925 sediment transport systems often showing little change in grain size over 100s of kilometres

926 (Amsler et al., 2007; Frings, 2008) in direct contrast to smaller, headwater streams (Ferguson

927 et al., 1996). Big rivers have significant reaches that are dominated by laterally migrating

928 channels because the wide and low-gradient floodplains provide accommodation space for

929 channel shifting that is possible because of available energy. Large rivers usually contain

930 significant (in terms of water and sediment discharge) tributaries, but unlike smaller rivers, big

931 rivers have 100s of kilometres to mix these incoming flows and sediments (Lane at al., 2008)

932 and therefore can absorb any potential perturbation from a new sediment input grain size or

933 volume (cf. Rice, 1998). Big rivers have partially- and temporarily-coupled channels and

934 floodplains (Figs 7A-B; see definitions and discussion in Lewin and Ashworth, in press)

935 where the dispersal and sediment storage overbank and in adjacent water bodies can be a

936 significant process for months of the year (Dunne et al., 1998; Day et al., 2008).

937 Some researchers have investigated whether the channel pattern and planform

938 morphology of anabranching rivers is the same for large and small rivers. It has been shown

939 convincingly that braided river network patterns are scale invariant (e.g., Sapozhnikov and

940 Foufoula-Georgiou, 1996; Nykanen et al., 1998; Sapozhnikov et al., 1998; Foufoula-Georgiou

941 and Sapozhnikov, 2001). Likewise, Sambrook Smith et al. (2005) and Kelly (2006) have

942 shown that surface planform (long-to-intermediate axis) of mid-channel bars is scale invariant

943 for a range of anabranching rivers over a four order of magnitude range in size. To some 
944 extent this latter result is not surprising given that mid-channel bars will always be

945 streamlined by the flow, but stark variations do exist, seemingly associated only with big

946 rivers. For example, over $1200 \mathrm{~km}$ of the Congo (shown in Fig. 3E) and $250 \mathrm{~km}$ of the Negro

947 (shown in Figs 5A-B) have mid-channel bars that are especially elongated (mean

948 intermediate-to-long axis of 0.25). It is unclear why these bars should have such different

949 planform morphologies from other large rivers (e.g. the Jamuna, Fig. 12) but it may be related

950 to the local bar-building process that is through inwardly-accreting levees and ridges (Figs

951 5A-B; Latrubesse and Franzinelli, 2005) and/or the influence of mature vegetation that

952 reduces the potential for avulsion and substantial reworking.

953 Previous work has shown that the world's largest rivers have main channels with different 954 cross-sectional morphologies than smaller rivers (Xu, 2004; Latrubesse, 2008). For example, 955 Latrubesse (2008) compiled data on the width:depth ratio for 16 large rivers that showed 956 most values were greater than 30 , with 5 greater than 100. Two of the world's largest rivers, 957 the Paraná and Jamuna, have channels with width:depth ratios greater than 200 and it has 958 been suggested that such channel geometries may suppress or prevent the development of 959 channel-wide secondary flows that are common in smaller rivers (McLelland et al., 1999; 960 Parsons et al., 2007). Despite widespread agreement that big rivers have different average 961 cross-sectional geometries than smaller rivers, there is a closer correspondence in maximum 962 relative depth of confluence scour for different types and sizes of rivers (Sambrook Smith et 963 al., 2005; their fig. 2, p. 148), therefore suggesting there are some similar underlying 964 processes governing the evolution of both small and large rivers. 


\section{Conclusions}

968

969 The world's largest rivers drain about half of the global continental land and are highly-refined

970 sediment transport systems. Most are generally low-gradient and fine-grained yet they are

971 strongly differentiated - much more so than most previously-studied smaller rivers. Big rivers

972 have several notable attributes:

973

974 1. Trans-continental rivers link up contrasted sets of erosion/sedimentation domains; 975 they are intrinsically more highly differentiated from one another and have greater 976 internally complexity along their courses than smaller monotonic fluvial systems.

2. Despite their high absolute values, sediment loadings in trans-continental rivers may have been considerably reduced by upstream sequestration. Perhaps counterintuitively, the largest rivers can also be sediment-poor for their size because major sub-catchments are low-yielding.

982

983 3. Alluvial settings are dependent on mainstream and tributary inputs of water and 984 sediment, but alluvial morphologies are essentially determined at the reach scale by 985 the variable sediment feeds and range of in-channel and channel-to-floodplain $986 \quad$ sediment exchange styles. 
988 4. Anabranching planform channel patterns dominate, with a system of multiple channels 989 that divide and rejoin. But anabranching is achieved by different processes, as is $990 \quad$ illustrated by the Ob, Jamuna and Paraná.

991

992 5. Big rivers contain a bewildering range of channel planforms - from single to multiple channels, some highly sinuous, with bars dominated by lateral accretion, but others by downstream migration and a floodplain that can be dominated by adjacent standing water bodies in a range of size that may be refilled during floods. Main channels can be straight, meandering, braided, wandering or anastomosing. Individual branch channel patterns are determined by the degree of lateral shifting and avulsion, rate of overbank sedimentation, magnitude of sediment transport capacity and bed material/braiding intensity.

6. Forms of alluvial exchange can be classified as: (i) deposition on the floodplain (e.g., levees, infilled palaeochannel, floodbasins), (ii) exchanges involving main channels (e.g., bank erosion and accretion), (iii) deposition within main channels (e.g. bedforms from metres to 10 s of kilometres in size), and (iv) material input from tributaries (sediment-rich or sediment-poor). Whilst the size of channels reflects formative water discharges, it is these variations in sediment exchange that produce the diversity of big river morphologies.

7. Fine out-of-channel sediment deposition may be insufficient to fill hydraulic corridors; ponded lacustrine environments are common. Water bodies vary from smaller water- 
filled swales and palaeochannels, to floodbasins between raised alluvial ridges and valley-sides, and to km-scale linear lakes in sediment-dammed tributaries. Organic sedimentation is significant along relatively sediment-poor and laterally-stable major rivers that fail to fill their alluvial corridors.

8. Hydraulic and sedimentation systems may be divided into four types: (i) lacustrinedominated, (ii) mainstream-dominated, (iii) tributary or accessory-stream dominated, and (iv) confined or bedrock-dominated.

9. Big rivers are commonly plural systems, with partial functional decoupling between large rivers and their hydraulic floodplains, and with accessory and tributary channels rather than main-river branches determining patterns of floodplain morphology. Straight, bedform-dominated mainstreams may have accessory channels that actively meander to dominate near-surface floodplain sedimentation.

10. Bed sediment transfers are dominated by migrating sandy bedforms but with a wide range of bar types, shapes and rates of accretion. No style of bar creation or aggradation is unique to big rivers and many barforms are short-lived, ephemeral features that wrap around or onto stable vegetated islands that control the planform morphology. Lobate, unit bars are rare or absent in some of the world's largest sandbed rivers. 
1051

1052

1053

1054
11. Some processes and patterns are different from smaller rivers, including: (i) less straight-forward sequencing of channel pattern downstream, (ii) main channels with high width:depth ratios and possibly limited channel-wide secondary flows, (iii) few or no channel-wide unit bars migrating through the main thalwegs, (iv) extensive and lowgradient floodplains that provide space for channel shifting and floodplain sedimentation, (v) long distances between significant tributaries to allow full mixing of water and sediment discharges, (vi) partial and sometimes temporarily decoupled channels and floodplains, (vii) significant floodplain water bodies that readily act as sinks for fine-grained and organic sediments.

12. There can be an apparent disconnect between observable channel processes and overall patterns of channels and floodplains. In part this arises from different activity timescales, in part from inheritance. The understanding of observed 'contemporary' forms requires attention to: flood-event transfer of sediment, reach-scale incremental reworking of floodplain sediments and bar changes on a timescale of years to centuries, and the inheritance and modification of floodplain forms and sediments that relate to Quaternary change. 


\section{Acknowledgements}

1058

PJA would like to thank the UK Natural Environment Research Council (NERC) for

1060 support under grant NE/E016022/1 that funded fieldwork on the Rio Paraná, Argentina,

1061 together with colleagues Mario Amsler, Jim Best, Rich Hardy, Stuart Lane, Andrew Nicholas,

1062 Oscar Orfeo, Dan Parsons, Arjan Reesink, Greg Sambrook Smith, Steve Sandbach and

1063 Ricardo Szupiany. Thanks to this team for allowing use of the jointly-collected data shown in

1064 Fig. 16. Fieldwork on the Jamuna was supported by NERC grant GR9/02034 to PJA and 1065 colleagues Jim Best, Charlie Bristow and Julie Roden. We are grateful to Chris Simpson of

1066 Fulcrum Graphic Communications Inc., Vancouver, B.C., for his expertise in sourcing and 1067 producing all the figures. Referees Gerald Nanson, Chris Fielding and Managing Editor

1068 Andrew Miall are all thanked for their insightful and supportive comments.

\section{References}

1071

1072 Aalto, R.E., Dunne, T., Guyot, J.L., 2006. Geomorphic controls on Andean denudation. 1073 Journal of Geology 114, 85-99.

1074 Abbado, D., Slingerland, R., Smith, N.D., 2005. Origin of anastomosis in the upper Columbia 1075 River, British Columbia, Canada. In: Blum, M.D., Marriot, S.B., Leclair, S.M. (Eds.), Fluvial 1076 Sedimentology VII. Special Publication of the International Association of 1077 Sedimentologists, 35, Blackwell, Oxford, UK, 3-15. 
1078 Adams, P.N., Slingerland, R.L., Smith, N.D., 2004. Variations in natural levee morphology in 1079 anastomosed channel flood plain complexes. Geomorphology 61, 127-142.

1080 Alabyan, A., Chalov, R., 1998. Types of river channel patterns and their natural controls. 1081 Earth Surface Processes and Landforms 23, 467-474.

1082 Allison, M.A., Kuehl, S.A., Martin, T.C., Hassan, A., 1998. Importance of flood-plain 1083 sedimentation for river sediment budgets and terrigenous input to the oceans: insights 1084 from the Brahmaputra-Jamuna River. Geology 26, 175-178.

1085 Amsler, M.L., Drago, E.C., 2009. A review of the suspended sediment budget at the 1086 confluence of the Paraná and Paraguay Rivers. Hydrological Processes 23, 3230-3235.

1087 Amsler, M.L., Garcia, M.H., 1997. Sand-dune geometry of large rivers during floods 1088 Discussion. Journal of Hydraulic Engineering 123(6), 582-585.

1089 Amsler, M.L., Drago, E.C., Paira, A.R., 2007. Fluvial sediments: main channel and floodplain 1090 interrelationships. In: Iriondo, M.H., Paggi, J.C., Parma, M.J. (Eds.), The Middle Paraná 1091 River. Springer-Verlag, Berlin, 123-141.

1092 Amsler, M. L., Ramonell, C. G., Toniolo, H. A., 2005. Morphologic changes in the Paraná 1093 River channel (Argentina) in the light of climate variability during the $20^{\text {th }}$ century. 1094 Geomorphology 70, 257-278. Doi:10.1016/j.geomorph.2005.02.008.

1095 Archer, A.W., 2005. Review of Amazonian depositional systems. In: Blum, M.D., Marriott, 1096 S.B., Leclair, S. (Eds.), Fluvial Sedimentology VII, Special Publication International 1097 Association of Sedimentologists 35, 17-39.

1098 Ashmore, P.E., 1991. How do gravel-bed rivers braid? Canadian Journal of Earth Sciences, $1099 \quad 28,326-341$. 
1100 Ashworth, P.J., Best, J.L., Roden, J.E., Bristow, C.S., Klaassen, G.J., 2000. Morphological

1101 evolution and dynamics of a large, sand braid-bar, Jamuna River, Bangladesh.

1102 Sedimentology 47, 533-555.

1103 Assine, M.L., Silva, A., 2009 Contrasting fluvial styles of the Paraguay River in the 1104 northwestern border of the Pantanal wetland, Brazil. Geomorphology 113, 189-199. DOI: $1105 \quad$ 10.1016/j.geomorph.2009.03.012.

1106 Baker, V.R. 2007. Greatest Floods and Largest Rivers. In: Gupta, A. (Ed.), Large Rivers: 1107 Geomorphology and Management, Wiley, Chichester, 65-74.

1108 Barua, D.K., 1994. On the environmental controls of Bangladesh river systems. Asia Pacific 1109 Journal on Environment and Development Bangladesh. 1, 81-98.

1110 Best, J.L., 2005. The fluid dynamics of river dunes: A review and some future research 1111 directions. Journal of Geophysical Research, 110 (F04S01). Doi:10.1029/2004JF000218.

1112 Best, J.L., Ashworth, P.J., 1997. Scour in large braided rivers and the recognition of 1113 sequence stratigraphic boundaries. Nature 387, 275-277.

1114 Best, J.L., Ashworth, P.J., Bristow, C.S., Roden, J.E., 2003. Three-dimensional sedimentary 1115 architecture of a large, mid-channel sand braid bar, Jamuna River, Bangladesh. Journal of 1116 Sedimentary Research 73, 516-530.

1117 Best, J.L., Ashworth, P.J., Sarker, M.H., Roden, J.E. 2007. The Brahmaputra-Jamuna River, 1118 Bangladesh. In: Gupta, A. (Ed.), Large Rivers: Geomorphology and Management. Wiley, 1119 Chichester, 395-433.

1120 Blondeaux, P., Seminara, G., 1985. A unified bar-bend theory of river meanders. Journal of 1121 Fluid Mechanics 157, 449-470. 
1122 Bobrovitskaya, N.N., Zubkova, C., Meade, R.H., 1996. Discharges and yields of suspended 1123 sediment in the Ob' and Yenisey Rivers of Siberia. In: Erosion and Sediment Yield: Global 1124 and Regional Perspectives, IASH Publication 236, 115-123.

1125 Brice, J.C., 1975. Air photo interpretation of the Form and Behaviour of Alluvial Rivers. Final 1126 Report to the US Army Research Office, $13 \mathrm{pp}$.

1127 Bridge, J.S., 1993. The interaction between channel geometry, water flow, sediment transport 1128 and deposition in braided rivers. In: Best, J.L., Bristow, C.S. (Eds.), Braided Rivers, 1129 Geological Society of London Special Publication, 75, 13-71.

1130 Bridge, J.S., 2003. Rivers and Floodplains: Forms, Processes and Sedimentary Record. $1131 \quad$ Blackwell, Malden, USA, 491pp.

1132 Bristow, C.S., 1987. Brahmaputra River: Channel migration and deposition. In: Ethridge, 1133 F.G., Flores, R.M., Harvey, M.D. (Eds.), Recent Developments in Fluvial Sedimentology, 1134 Special Publication Society Economic Palaeontology and Mineralogy 39, 63-74.

1135 Bristow, C.S.. 1993. Sedimentary structures in bar tops in the Brahmaputra River, 1136 Bangladesh. In: Best, J.L., Bristow, C.S. (Eds.), Braided Rivers, Special Publication $1137 \quad$ Geological Society, 75, 277-289.

1138 Bristow, C.S., 1999. Avulsion, river metamorphosis and reworking by underfit streams: a 1139 modern example from the Brahmaputra River in Bangladesh and a possible ancient 1140 example in the Spanish Pyrenees. In: Smith, N.D., Rogers, J. (Eds.), Fluvial 1141 Sedimentology VI. International Association of Sedimentologists, Special Publication, 28, 1142 221-230.

1143 Brooks, G.R., 2003. Alluvial deposits of a mud-dominated stream: the Red River, Manitoba, $1144 \quad$ Canada. Sedimentology 50, 441-458. 
1145 Burge, L.M., Lapointe, M.F., 2005. Understanding the temporal dynamics of the wandering

1146 Renous River, New Brunswick, Canada. Earth Surface Processes and Landforms, 30, 1147 1227-1250. Doi: 10.1002/esp.1196.

1148 Carson M.A., 1984. Observations on the meandering-braided river transition, the Canterbury 1149 plains, New Zealand: part two. New Zealand Geographer 40(2), 89-99.

1150 Chen, Z., Xu. K., Watanabe, M. 2007. Dynamic hydrology and geomorphology of the Yangtze 1151 River. In: Gupta, A. (Ed.), Large Rivers: Geomorphology and Management. Wiley, 1152 Chichester, 457- 469

1153 Chowdhury, M.R., 2000. An assessment of flood forecasting in Bangladesh: the experience 1154 of the 1998 flood. Natural Hazards 22, 139-169.

1155 Church, M., 2006. Bed material transport and the morphology of alluvial rivers. Annual 1156 Review of Earth and Planetary Sciences 34, 325-354.

1157 Church, M., Jones, D., 1982. Channel bars in gravel-bed rivers. In: Hey, R.D., Bathurst, J.C., 1158 Thorne, C.R. (Eds.), Gravel-bed rivers. John Wiley and Sons, Chichester, UK, 291-336.

1159 Church, M., Kellerhals, R., Day, T.J., 1989. Regional clastic sediment yield in British 1160 Columbia. Canadian Journal of Earth Sciences 26, 31-45.

1161 Coleman, J.M., 1969. Brahmaputra River: channel processes and sedimentation, 1162 Sedimentary Geology 3, 129-239.

1163 Constantine, J.A., Dunne, T., Piégay, H., Kondolf, G.M., 2010. Controls on the alluviation of 1164 oxbow lakes by bed-material load along the Sacramento River, California. Sedimentology 1165 57, 389-407. Doi 10.1111/j.1365-3091.2009.01084.x 
1166 Costard, F., Gautier, E., 2007. The Lena River: hydromorphodynamic features in a deep

1167 permafrost zone. In: Gupta, A. (Ed.), Large Rivers: Geomorphology and Management.

1168 Wiley, Chichester, 225-233.

1169 Davidson, S.K., North, C.P., 2009. Geomorphological regional curves for prediction of 1170 drainage area and screening modern analogues for rivers in the rock record. Journal of 1171 Sedimentary Research 79, 773-792. Doi 10.2110/jsf.2009.080

1172 Day, G., Dietrich, W.E., Rowland, J.C., Marshall, A., 2008. The depositional web on the 1173 floodplain of the Fly River, Papua New Guinea. Journal of Geophysical Research 113, $1174 \quad$ F01S02. Doi:10.1029/2006JF000622.

1175 Drago, E.C., 2010. Notes on the upstream growth of sand bars in large rivers. The case of 1176 the Paraná River. Instituto Nacional de Limnologia (INALI). Cientificas y Técnicas de 1177 Argentina, October 2010, 14 pp.

1178 Drago, E.C., Ezcurra de Drago, I., Oliveros, O., Paira, A., 2003. Aquatic habitats, fish and 1179 invertebrate assemblages of the Middle Paraná River, Argentina. Amazoniana 17, 291$1180 \quad 341$

1181 Dunne, T., Mertez, L.A.K., Richey, J.E., Forsberg, B.R., 1998. Exchanges of sediment 1182 between the floodplain and the channel of the Amazon River in Brazil. Geological Society 1183 of America Bulletin 110, 450-467.

1184 Eaton, B., Millar, R., Davidson, S., 2010. Channel patterns: braided, anabranching, and 1185 single-threaded. Geomorphology 120, 353-364.

1186 EGIS (Environmental and GIS Support Project for Water Sector Planning), 1997. 1187 Morphological dynamics of the Brahmaputra-Jamuna River. Prepared for Water 1188 Resources Planning Organization, Dhaka, Bangladesh, 76 pp.Ferguson, R.I., 1987. 
1189 Hydraulic and sedimentary controls of channel pattern. In: Richards, K.S. (Ed.). River 1190 Channels: Environment and Process, Blackwell, Oxford, 129-158.

1191 Ferguson, R.I., Hoey, T.B., Wathen, S.J., Werritty, A., 1996. Field evidence for downstream 1192 fining of river gravels through selective transport. Geology, 24, 179-182.

1193 Fielding, C.R., 2007. Sedimentology and stratigraphy of large river deposits: recognition in 1194 the ancient record, and distinction from "incised valley fills". In: Gupta, A. (Ed.), Large 1195 Rivers: Geomorphology and Management, Wiley, Chichester, 97-113.

1196 Fielding, C.R., Ashworth, P.J., Best, J.L., Prokocki, E.W., Sambrook Smith, G.H., in press. 1197 Tributary, distributary and other fluvial patterns: what really represents the norm in the 1198 continental rock record? Sedimentary Geology. DOI: 10.1016/j.sedgeo.2012.03.004.

1199 Flood Action Plan 24; Delft Hydraulics and DHI, 1996a. FAP24 River Survey Project, Final 1200 Report, Main Volume (prepared for FPCO), Dhaka, Bangladesh, 280 pp.

1201 Flood Action Plan 24; Delft Hydraulics and DHI, 1996b. FAP24 River Survey Project, Final 1202 Report - Annex 3: Hydrology, (prepared for FPCO), Dhaka, Bangladesh.

1203 Foufoula-Georgiou, E., Sapozhnikov, V., 2001. Scale invariances in the morphology and 1204 evolution of braided rivers. Mathematical Geology 33, 273-291.

1205 Frings, R.M., 2008. Downstream fining in large sand-bed rivers. Earth-Science Reviews 87, $120639-60$.

1207 Froese, D.G., Smith, D.G., Clement, D.T., 2005. Characterizing large river history with 1208 shallow geophysics: Middle Yukon River, Yukon Territory and Alaska. Geomorphology 67, 1209 391-406. Doi: 10.1016/j.geomorph.2004.11.011. 
1210 Garcia, M.H., 2008. Sediment transport and morphodynamics. In: Garcia, M.H. (Ed.),

1211 Sedimentation Engineering: Processes, Management, Modeling, and Practice. American

1212 Society of Civil Engineers, Virginia, USA, 21-146.

1213 Goudie, A.S., 2005. The drainage of Africa since the Cretaceous. Geomorphology 67, 4371214456.

1215 Gibling, M.R., 2006. Width and thickness of fluvial channel bodies and valley fills in the 1216 geological record: a literature compilation and classification. Journal of Sedimentary $1217 \quad$ Research 76, 731-770.

1218 Gomez, B., Eden, D.N., Hicks, D.M., Trustrum, N.A., Peacock, D.H., Wilmhurst, J., 1999. 1219 Contribution of floodplain sequestration to the sediment budget of the Waipaoa River, New 1220 Zealand. In: Marriott, S.B., Alexander, J. (Eds.), Floodplains: Interdisciplinary Approaches, 1221 Special Publication Geological Society of London 163, 69-88.

1222 Goodbred, S.L., Kuehl, S.A., 1999. Holocene and modern sediment budgets for the Ganges1223 Brahmaputra River system: evidence for highstand dispersal to flood-plain, shelf and 1224 deep-sea depocentres. Geology 27, 559-562. Doi: 10.1130/0091-7613.

1225 Grabowski, R.C., Droppo, I.G., Wharton, G., 2011. Erodibility of cohesive sediment: The 1226 importance of sediment properties. Earth-Science Reviews 105, 101-120. Doi: $1227 \quad$ 10.1016/j.earscirev.2011.01.008.

1228 Gupta, A., (Ed.), 2007. Large Rivers: Geomorphology and Management. Wiley, Chichester, $1229 \quad 689 p p$.

1230 Hartley, A.J., Weissmann, G.S., Nichols, G.J., Warwick, G.L., 2010. Large distributive fluvial 1231 systems: Characteristics, distribution, and controls on development. Journal of 1232 Sedimentary Research 80, 167-183. Doi:10.2110/jsr.2010.016. 
1233 Holeman, J.N., 1968. The sediment yield of major rivers of the world. Water Resources $1234 \quad$ Research 4, 737-747.

1235 Hovius, N., 1998. Controls on sediment supply by large rivers. In: Shanley, K.W., McCabe,

1236 P.J. (Eds.), Relative Role of Eustasy, Climate and Tectonics in Continental Rocks, SEPM 1237 Special Publication 59, Tulsa Oklahoma, 4-15.

1238 Ikeda, S., Parker, G. (Eds.). 1989. River Meandering. Water Resources Monograph 12, $1239 \quad$ American Geophysical Union, Washington DC. 485pp.

1240 Iriondo, M.H., 2007. Geomorphology. In: Iriondo, M.H., Paggi, J.C., Parma, M.J. (Eds.), The 1241 Middle Paraná River. Springer-Verlag, Berlin, 33-52.

1242 Iriondo, M.H., Paggi, J.C., Parma, M.J. (Eds.), 2007. The Middle Paraná River. Springer1243 Verlag, Berlin, 382pp.

1244 Islam, M.R., Begum, S.F., Yamaguchi, Y., Ogawa, K., 1999. The Ganges and Brahmaputra 1245 rivers in Bangladesh: basin denundation and sedimentation. Hydrological Processes 13, $1246 \quad 2907-2923$.

1247 ISPAN (FAP 16 and FAP 19), 1993. The dynamic physical and human environment of 1248 riverine charlands: Jamuna. Dhaka, Bangladesh.

1249 ISPAN (FAP 16 and FAP 19), 1995. A study of sedimentation in the Brahmaputra-Jamuna $1250 \quad$ Floodplain. Dhaka, Bangladesh.

1251 Jerolmack, D.J., Mohrig, D., 2007. Conditions for branching in depositional rivers. Geology 1252 35, 463-466. Doi: 10.1130/G23308A.1.

1253 Jerolmack, D. J., Paola, C., 2010. Shredding of environmental signals by sediment transport. 1254 Geophysical Research Letters 37, L19401. Doi:10.1029/2010GL044638. 
1255 Julien, P.Y., Klaassen, G.J., 1995. Sand-dune geometry of large rivers during floods. Journal 1256 of Hydraulic Engineering 121, 657-663.

1257 Julien, P.Y., Klaassen, G.J. 1997. Closure of Discussion 'Sand-dune geometry of large rivers 1258 during floods'. Journal of Hydraulic Engineering 123, 584-585.

1259 Kelly, S., 2006. Scaling and hierarchy in braided rivers and their deposits: examples and 1260 implications for reservoir modelling. In: Sambrook Smith, G.H., Best, J.L., Bristow, C.S., 1261 Petts, G.E. (Eds.), Braided rivers: process, deposits, ecology and management. Special 1262 Publication of the International Association of Sedimentologists, 36, Blackwell, Oxford, 75$1263 \quad 106$.

1264 Khan, N.I., Islam, A., 2003. Quantification of erosion patterns in the Brahmaputra-Jamuna 1265 River using geographical information system and remote sensing techniques. Hydrological 1266 Processes 17, 959-966.

1267 Klaassen, G.J., Vermeer, K., 1988. Confluence scour in a large braided river with fine bed 1268 material. Proceedings of the International Conference on Fluvial Hydraulics, Budapest, 1269 Hungary, 395-408.

1270 Klaassen, G.J., Vermeer, K., Uddin, N., 1988. Sedimentological processes in the Jamuna 1271 (Lower Brahmaputra) river, Bangladesh. Proceedings of the International Conference on 1272 Fluvial Hydraulics. Budapest, Hungary, 381-394.

1273 Kleinhans, M.G., 2010. Sorting out river channel patterns. Progress in Physical Geography, 1274 34(3), 287-326. Doi: 10.1177/0309133310365300.

1275 Kleinhans, M.G., Van den Berg, J.H., 2011. River channel and bar patterns explained and 1276 predicted by an empirical and a physics-based method. Earth Surface Processes and 1277 Landforms, 36, 721-735. Doi: 10.1002/esp.2090. 
1278 Kocurek, G., Ewing, R.C., Mohrig, D. 2010. How do bedform patterns arise? New views on 1279 the role of bedform interactions within a set of boundary conditions. Earth Surface $1280 \quad$ Processes and Landforms 35, 51-63. Doi: 10.1002/esp.1913.

1281 Knighton, D., Nanson, G., 1993. Anastomosis and the continuum of channel pattern. Earth $1282 \quad$ Surface Processes and Landforms, 18, 613-625.

1283 Kondrat'yev, N.Y. 1968. Hydromorphological principles of computation of free meandering. 1284 1.Signs and indexes of free meandering. Soviet Hydrology 4, 309-335.

1285 Kondrat'yev, N.Y., Popov, I.V., 1967. Methodological prerequisits for conducting network 1286 observations on the channel process. Soviet Hydrology 3, 273-297.

1287 Kostaschuk, R., Villard, P. 1996. Flow and sediment transport over large subaqueous dunes: $1288 \quad$ Fraser River, Canada. Sedimentology 43, 849-863.

1289 Kostaschuk, R., Shugar, D., Best, J., Parsons, D., Lane, S., Hardy, R. and Orfeo, O., 2009. 1290 Suspended sediment transport and deposition over a dune: Rio Paraná, Argentina. Earth 1291 Surface Processes and Landforms 34, 1605-1611. DOI: 10.1002/esp.1847.

1292 Kulemina, N.M., 1973. Some characteristics of the process of incomplete meandering of the 1293 channel of the upper Ob' River. Soviet Hydrology 6, 518-534.

1294 Kuhlne, R., 2007. Sediment transport measurements. In: Garcia, M.H. (Ed.), Sedimentation 1295 Engineering: Processes, Management, Modeling, and Practice. American Society of Civil 1296 Engineers, Virginia, USA, 339-346.

1297 Lambert, C.P., Walling, D.E., 1987. Floodplain sedimentation: a preliminary investigation of 1298 contemporary deposition within the lower reaches of the River Culme, Devon, UK. 1299 Geografiska Annaler 69A, 47-59. 
1300 Lane, S.N., Parsons, D.R., Best, J.L., Orfeo, O., Kostaschuk, R., Hardy, R.J., 2008. Causes

1301 of rapid mixing at a junction of two large rivers: Río Paraná and Río Paraguay, Argentina.

1302 Journal of Geophysical Research, 113, F02019. Doi: 10.1029/2006JF000745.

1303 Latrubesse, E.M. 2008. Patterns of anabranching channels: the ultimate end-member 1304 adjustment of mega rivers. Geomorphology 101, 130-145.

1305 Doi:10.1016/j.geomorph.2008.05.035.

1306 Latrubesse, E.M., Franzinelli, E., 2002. The Holocene alluvial plain of the middle Amazon $1307 \quad$ River, Brazil. Geomorphology 44, 241-257.

1308 Latrubesse, E.M., Franzinelli, E., 2005. The late Quaternary evolution of the Negro River,

1309 Amazon, Brazil: implications for island and floodplain formation in large anabranching $1310 \quad$ tropical systems. Geomorphology 70, 372-397.

1312 Latrubesse, E.M., Cozzuol, M., da Silva-Caminha, S.A.F., Rigsby, C.A., Absy, M.L., 1313 Jaramillo, C., 2010. The Late Miocene paleogeography of the Amazon Basin and the 1314 evolution of the Amazon River system. Earth-Science Reviews 99, 99-124. DOI: 1315 10.1016/j.earscirev.2010.02.05.Latrubesse, E.M., Stevaux, J.C., Sinha, R., 2005. Tropical 1316 rivers. Geomorphology 70, 187-206.

1317 Leddy, J.O., Ashworth, P.J., Best, J.L., 1993. Mechanisms of anabranching avulsion within 1318 gravel-bed braided rivers: observations from a scaled physical model. In: Best, J.L., 1319 Bristow, C.S. (Eds.), Braided Rivers. Geological Society of London Special Publication 75, $1320 \quad 119-127$.

1321 Leclair, S.F., 2011. Interpreting fluvial hydromorphology from the rock record: large-river peak 1322 flows leave no clear signature. In: Davidson, S.K., Leleu, S., North, C.P. (Eds.), From 
1323 River to Rock Record: the Preservation of Fluvial Sediments and their Subsequent 1324 Interpretation. SEPM Special Publication, 97, 113-124.

1325 Leopold, L.B., Wolman, M.G., 1957. River channel patterns: braided, meandering and 1326 straight. US Geological Survey Professional Paper, 262-B, 50pp.

1327 Lewin, J., 1976. Initiation of bedforms and meanders in coarse-grained sediment. Geological 1328 Society of America Bulletin 87, 281-285.

1329 Lewin, J., Ashworth, P.J., in press. Defining large river channel patterns: alluvial exchange 1330 and plurality. Geomorphology.

1331 Lewin, J., Brewer, P.A., 2001. Predicting channel patterns. Geomorphology 40, 329-339.

1332 Lucci, R., Zolezzi, G., Tubino M., 2010. Modelling mid-channel bars in meandering channels.

$1333 \quad$ Earth Surface Processes and Landforms 35, 902-917.

1334 Makaske, B., 2001. Anastomosing rivers: a review of their classification, origin and 1335 sedimentary products. Earth-Science Reviews 53, 149-196.

1336 Makaske, B., Smith, D.G., Berendson, H.J.A., de Boer, A.G., Nielen-Kiezebrink, M.F., 1337 Locking, T., 2009. Hydraulic and sedimentary processes causing anastomosing 1338 morphology of the upper Columbia River, British Columbia, Canada. Geomorphology 111, $1339 \quad$ 194-205.

1340 Maroulis, J.C., Nanson, G.C., 1996. Bedload transport of aggregated muddy alluvium from 1341 Cooper Creek, central Australia; a flume study. Sedimentology 43: 771-790

1342 MCLelland, S.J., Ashworth, P.J., Best, J.L., Roden, J.E., Klaassen, G.J., 1999. Flow structure 1343 and transport of sand-grade suspended sediment around an evolving braid-bar, Jamuna 1344 River, Bangladesh. In: Smith, N.D., Rogers, J. (Eds.), Fluvial Sedimentology VI, Special 1345 Publication of the International Association of Sedimentologists 28, 43-57. 
1346 Marron, D.C., 1992. Floodplain storage of mine tailings in the Belle Fourche River system: a

1347 sediment budget approach. Earth Surface Processes and Landforms 17, 675-685.

1348 Meade, R.H., 2007. Transcontinental moving and storage: The Orinoco and Amazon Rivers

1349 transfer the Andes to the Atlantic. In: Gupta, A. (Ed.), Large Rivers: Geomorphology and

1350 Management. Wiley, Chichester, 45-63.

1351 Meade, R.H., Bobrovitskaya, N.N., Babkin, V.I., 2000. Suspended-sediment and fresh-water 1352 discharges in the Ob and Yenisey rivers, 1960-1988. International Journal of Earth 1353 Sciences 89, 461-469.

1354 Meade, R.H., Parker, R.S., 1985. Sediment in rivers of the United States. U.S. Geological 1355 Survey Water-Supply Paper 2275, 49-60.

1356 Mertes, L.A.K., Dunne, T., 2007. Effects of tectonism, climatic change, and sea-level change 1357 on the form and behaviour of the modern Amazon River and its floodplain. In: Gupta, A. 1358 (Ed.), Large Rivers: Geomorphology and Management. Wiley, Chichester, 115-144.

1359 Mertes, L.A.K., Dunne, T., Martinelli, L.A., 1996. Channel-floodplain geomorphology along 1360 the Solimões-Amazon River, Brazil. Geological Society of America Bulletin 108, 1089$1361 \quad 1107$.

1362 Métivier, F., Gaudemer, Y., 1999. Stability of output fluxes of large rivers in South and East 1363 Asia during the last 2 million years: implications on floodplain processes. Basin Research $1364 \quad 11,293-303$.

1365 Miall, A.D., 1996. The Geology of Fluvial Deposits: Sedimentary Facies, Basin Analysis and 1366 Petroleum Geology. Springer-Verlag, Heidelberg, 582pp.

1367 Miall, A.D., 2006. How do we identify big rivers? And how big is big? Sedimentary Geology 1368 186, 39-50. Doi: 10.1016/j.sedgeo.2005.10.001. 
1369 Milliman, J.D., Meade, R.H., 1983. World-wide delivery of river sediment to the ocean. $1370 \quad$ Journal of Geology 91, 1-21.

1371 Milliman, J.D., Syvitski, J.P.M., 1992. Geomorphic/Tectonic Control of sediment discharge to 1372 the ocean: the importance of small mountain rivers. Journal of Geology 100, 525-544.

1373 Mosselman, E., 2006. Bank protection and river training along the braided Brahmaputra1374 Jamuna River, Bangladesh, In: Sambrook Smith, G.H., Best, J.L., Bristow, C.S., Petts, 1375 G.E. (Eds.), Braided rivers: process, deposits, ecology and management. Special 1376 Publication of the International Association of Sedimentologists, 36, Blackwell, Oxford, $1377 \quad 277-289$.

1378 Nanson, G.C., 1980. Point bar and floodplain formation of the meandering Beatton River, 1379 N.E. British Columbia, Canada. Sedimentology 27, 3-29.

1380 Nanson, G.C., Gibling, M., 2004. Anabranching and anastomosing river, In: Goudie, A.S. 1381 (Ed.), Encyclopedia of Geomorphology. Routledge, London, 21-25.

1382 Nanson, G.C., Knighton, A.D., 1996. Anabranching rivers: their cause, character and 1383 classification. Earth Surface Processes and Landforms 21, 217-239.

1384 Neill C.R., 1973. Hydraulic and morphologic characteristics of the Athabaska River near Fort 1385 Assiniboine. Report REH/73/3, Alberta Research Council, Highway River Engineering 1386 Division: Edmonton, 23 pp.

1387 Neill, C.R., 1987. Sediment balance considerations linking long-term transport and channel 1388 processes. In: Thorne, C.R., Bathurst, J.C., Hey, R.D. (Eds.), Sediment transport in gravel1389 bed rivers. John Wiley and Sons, Chichester, 225-240.

1390 Nicholas, A.P., Sandbach, S.D., Ashworth, P.J., Amsler, M.L., Best, J.L., Hardy, R.J., Lane, 1391 S.N., Orfeo, O., Parsons, D.R., Reesink, A.J.H., Sambrook Smith, G.H., Szupiany, R.N., in 
press. Modelling hydrodynamics in the Rio Paraná, Argentina: an evaluation and intercomparison of reduced-complexity and physics-based models applied to a large sand-bed

1394 river. Geomorphology.

1395 Nittrouer, J.A., Allison, M.A., Campanella, R., 2008. Bedform transport rates for the 1396 lowermost Mississippi River. Journal of Geophysical Research 113, F03004. 1397 Doi:10.1029/2007JF000795.

1398 Nykanen, D.K., Foufoula-Georgiou, E., Sapozhnikov, V.B., 1998. Study of spatial scaling in 1399 braided river patterns using synthetic aperture radar imagery. Water Resources Research, $1400 \quad 34,1795-1807$.

1401 Orfeo, O., Stevaux, J., 2002. Hydraulic and morphological characteristics of middle and 1402 upper reaches of the Paraná River (Argentina and Brazil). Geomorphology 44, 309-322.

1403 Paira, A.R., Drago, E.C., 2006. Genetical, morphological and evolutional relationships of the 1404 floodplain lakes in the Middle Paraná River hydrosystem. Zeitschrift für Geomorphologie, $1405 \quad 145,207-228$

1406 Paira A,R,, Drago, E.C., 2007. Origin, evolution, and types of floodplain water bodies. In: 1407 Iriondo M.H., Paggi J.C., Parma, M.J. (Eds.), The Middle Paraná River. Springer-Verlag: $1408 \quad$ Berlin; 53-81.

1409 Paola, C., Borgman, L., 1991. Reconstructing random topography from preserved $1410 \quad$ stratification. Sedimentology 38, 553-565.

1411 Parker, G., Shimizu, Y., Wilkerson, G.V., Eke, E.C., Abad, J.D., Lauer, J.D., Paola, C., 1412 Dietrich, W.E., Voller, V.R., 2011. A new framework for modeling the migration of 1413 meandering rivers. Earth Surface Processes and Landforms 36, 70-86. DOI: $1414 \quad$ 10.1002/esp.2113. 
1415 Parsons, D.R., Best, J.L., Orfeo, O., Hardy, R.J., Kostaschuk, R., Lane, S.N., 2005. 1416 Morphology and flow fields of three-dimensional dunes, Rio Paraná, Argentina: Results 1417 from simultaneous multibeam echo sounding and acoustic Doppler current profiling, 1418 Journal of Geophysical Research 110, 1-9. Doi:10.1029/2004JF000231.

1419 Parsons, D.R., Best, J.L., Lane, S.N., Orfeo, O., Hardy, R.J., Kostaschuk, R., 2007. Form 1420 roughness and the absence of secondary flow in a large confluence-diffluence, Rio 1421 Paraná, Argentina. Earth Surface Processes and Landforms 32, 155-162.

1422 Potter, P.E., 1978. Significance and origin of big rivers. Journal of Geology 86, 13-33.

1423 Ramonell, C.G., Amsler, M.L., Toniolo, H.A., 2002. Shifting modes of the Paraná River 1424 thalweg in its middle-lower reaches. Zeitschrift für Geomorphologie Suppl.-Bd. 129, 1291425142.

1426 Rice, S., 1998. Which tributaries disrupt downstream fining along gravel-bed rivers? 1427 Geomorphology 22, 39-56.

1428 Richardson, W.R.R., Thorne, C.R., 1998. Secondary currents around braid bar in 1429 Brahmaputra River, Bangladesh. Journal of Hydraulic Engineering 124, 325-328.

1430 Roden, J.E., 1998. Sedimentology and dynamics of mega-sand dunes, Jamuna River, 1431 Bangladesh. Unpublished Ph.D. thesis, University of Leeds, UK, 310 pp.

1432 Rowland, J.C., Lepper, K., Dietrich, W.E., Wilson, C.J., Sheldon, R., 2005. Tie channel 1433 sedimentation rates, oxbow formation age and channel migration from optically stimulated 1434 luminescence (OSL) analysis of floodplain deposits. Earth Surface Processes and $1435 \quad$ Landforms 30, 1161-1179.

1436 Roy, N.G., Sinha, R., Gibling, M.R., 2012. Aggradation, incision and interfluve flooding in the 1437 Ganga Valley over the past 100,000 years: Testing the influence of monsoonal 
precipitation. Palaeogeography, Palaeoclimatology,

Palaeoecology.

DOI: 10.1016/j.palaeo.2011.08.012.

1440 Rozo, M.G., Nogueira, A.C.R., Truckenbrodt, W. 2012. The anastomosing pattern and the 1441 extensively distributed scroll bars in the middle Amazon River. Earth Surface Processes 1442 and Landforms. DOI: 10.1002/esp.3249.

1443 Rust, B.R., 1978. A classification of alluvial channel systems. In: Miall, A.D. (Ed.), Fluvial 1444 Sedimentology. Canadian Society of Petroleum Geologists, Calgary, 187-198.

1445 Sioli, H., 1984. The Amazon and its main affluents: hydrography, morphology of the river 1446 courses, and river types. In: Sioli, H. (Ed.), The Amazon - Limnology and Landscape 1447 Ecology of a Mighty Tropical River and its Basin. Monographiae Biologicae 56, Junk, 1448 Dordrecht, 127-165.

1449 Sambrook Smith, G.H., Ashworth, P.J., Best, J.L., Lunt, I.A., Orfeo, O., Parsons, D.R., 2009. 1450 The sedimentology and alluvial architecture of a large braid bar, Río Paraná, Argentina. 1451 Journal of Sedimentary Research 79, 629-642. Doi: 10.2110/jsr.2009.066

1452 Sambrook Smith, G.H., Ashworth, P.J., Best, J.L., Woodward, J., Simpson, C.J., 2005. The 1453 morphology and facies of sandy braided rivers: some considerations of scale invariance. 1454 In: Blum, M.D., Marriott, S.B., Leclair, S.F. (Eds.), Fluvial Sedimentology VII. International 1455 Association of Sedimentologists, Special Publication 35, 145-158, Blackwells.

1456 Sambrook Smith, G.H., Ashworth, P.J., Best, J.L., Woodward, J., Simpson, C.J., 2006. The 1457 sedimentology and alluvial architecture of the sandy braided South Saskatchewan River, 1458 Canada. Sedimentology 53(2), 413-434. 
1459 Sambrook Smith, G.H., Best, J.L., Ashworth, P.J., Fielding, C.R., Goodbred, S.L., Prokocki, 1460 E.W., 2010. Fluvial form in modern continental sedimentary basins: Distributive fluvial 1461 systems: COMMENT. Geology 2010;38; e230. Doi: 10.1130/G31507C.1.

1462 Sandbach, S.D., Lane, S.N., Hardy, R.J., Amsler, M.L., Ashworth, P.J., Best, J.L., Nicholas, 1463 A.P., Orfeo, O., Parsons, D.R., Reesink, A.J.H., Sambrook Smith, G.H., Szupiany, R.N., in 1464 press. Application of a roughness-length representation to parameterize energy-loss in 3D 1465 numerical simulations of large rivers. Water Resources Research.

1466 Sandbach, S.D., Hardy, R.J., Lane, S.N., Parsons, D.R., Best, J.L., Ashworth, P.J., Reesink, 1467 A.J.H., Amsler, M.L., Szupiany, R.N., Nicholas, A.P., Orfeo, O., Sambrook Smith, G.H., 1468 2010. Three-dimensional modelling of a very large river: the Rio Paraná. In: Dittrich, A., 1469 Koll, Ka., Aberle, J., Geisenhainer, P. (Eds.), River Flow 2010. Brawnschehhe, Germany, $1470 \quad$ pp. 409-417, Bundesanstalt fuer Wasserbau.

1471 Santos, M. L., Stevaux, J. C., 2000. Facies and architectural analysis of channel sandy 1472 macroforms in the upper Paraná River. Quaternary International 72, 87-94.

1473 Sapozhnikov, V.B., Foufoula-Georgiou, E., 1996. Self-affinity in braided rivers. Water $1474 \quad$ Resources Research 33, 1983-1991.

1475 Sapozhnikov, V.B., Murray, A.B., Paola, C., Foufoula-Georgiou, E., 1998. Validation of 1476 braided-stream models: spatial state-space plots, self-affine scaling, and island shapes. Water Resources Research 34, 2353-2364.

1478 Sarker, M.H., Thorne, C.R. 2006. Morphological response of the Brahmaputra-Padma-Lower 1479 Meghna River system to the Assam earthquake of 1950. In: Sambrook Smith, G.H., Best, 1480 J.L., Bristow, C.S., Petts, G. (Eds.), Braided Rivers: process, deposits, ecology and 
management. Special Publication of the International Association of Sedimentologists, 36, 289-310.

1483 Schumm, S.A., 1977. The Fluvial System. Wiley, New York, 338pp.

1484 Schumm, S.A., 1981. Evolution and response of the fluvial system, sedimentologic 1485 implications. In: Ethridge, F.G., Flores R.M. (Eds.). Recent and Ancient Nonmarine 1486 Depositional Environments. Special Publication, Society Economic Palaeontology and $1487 \quad$ Mineralogy 31, 19-29.

1488 Schumm, S.A., Winkley, B.R. (Eds.), 1994. The Variability of Large Alluvial Rivers, American 1489 Association of Civil Engineers Press, New York. 467pp.

1490 Shugar, D., Koastaschuk, R., Best, J.L., Parsons, D.R., Lane, S.N., Orfeo, O., Hardy, R.J., 1491 2010. On the relationship between flow and suspended sediment transport over a crest of 1492 a sand dune, Rio Paraná, Argentina. Sedimentology 57(1), 252-272. Doi: 10.1111/j.1365$1493 \quad 3091.2009 .01110 . x$

1494 Shiklomanov I.A., Rodda J.C. (Eds.), 2003. World Water Resources at the Beginning of the 1495 Twenty-first Century. Cambridge University Press, Cambridge.

1496 Singh, I.B. 2007. The Ganga River. In: Gupta, A. (Ed.), Large Rivers: Geomorphology and 1497 Management. Wiley, Chichester, 347-371.

1498 Slingerland, R., Smith, N.D. 2004. River avulsions and their deposits. Annual Reviews Earth 1499 and Planetary Science, 32, 257-285.

1500 Smith, N.D., 1971. Transverse bars and braiding in the Lower Platte River, Nebraska. 1501 Geological Society of America Bulletin 82, 3407-3420.

1502 Smith, N.D., Smith, D.G., 1984. William River: an outstanding example of channel widening $1503 \quad$ and braiding caused by bed-load addition. Geology 12, 78-82. 
1504 Smith, J.D., McLean, S.R., 1977. Spatially-averaged flow over a wavy surface. Journal of 1505 Geophysical Research 82, 1735-1746.

1506 Swanson, K.M., Watson, E., Aalto, R., Lauer, J.W., Bera, M.T., Marshall, A., Taylor, M.P.,

1507 Apte, S.C., Dietrich, W.E. 2008. Sediment load and floodplain deposition rates:

1508 Comparison of the Fly and Strickland Rivers, Papua New Guinea. Journal of Geophysical

1509 Research 113, F01S03. Doi:10.1029/2006JF000623.

1510 Syvitski, J.P.M., Kettner, A., 2011. Sediment flux and the Anthropocene. Philosophical

1511 Transactions of the Royal Society A, 369: 957-975. Doi.10.1098/rsta.2010.0329.

1512 Syvitski, J.P.M., Vörősmarty, C.J., Kettner, A.J., Green, P. 2005. Impact of humans on the 1513 flux of terrestrial sediment to the global coastal ocean. Science 308, 376-380.

1514 Szupiany R.N., Amsler, M.L., Parsons, D.R., Best, J.R., 2009. Morphology, flow structure, 1515 and suspended bed sediment transport at two large braid-bar confluences. Water 1516 Resources Research 45. doi: W05415. Doi:10.1029/2008WR007428.

1517 Ten Brinke, W.B.M., Schoore, M.M., Sorber, A.M., Berendsen, H.J.A., 1998. Overbank 1518 deposits in relation to transport volumes during large-magnitude floods on the Dutch sand1519 bed Rhine river system. Earth Surface Processes and Landforms 23, 809-824.

1520 Ten Brinke, W.B.M., Wilbers, A.W.E., Wesseling, C., 1999. Dune growth, decay and 1521 migration rates during a large-magnitude flood at a sand and mixed sand-gravel bed in the 1522 Dutch Rhine river system. In: Smith, N.D., Rogers, J. (Eds.), Fluvial Sedimentology VI. 1523 International Association of Sedimentologists, Special Publication, 28, 15-32.

1524 Thorne, C.R., Russell, A.P.G., Alam, M.K. 1993. Planform pattern and channel evolution of 1525 the Brahmaputra River, Bangladesh. In: Best. JL. and Bristow, C.S. (Eds.), Braided Rivers, 1526 Special Publication of the Geological Society of London, 75, 257-276. 
1527 Tooth, S. 1999. Downstream changes in floodplain character on the Northern Plains of arid

1528 central Australia. In: Smith, N.D., Rogers, J. (Eds.), Fluvial Sedimentology VI. International

1529 Association of Sedimentologists, Special Publication, 28, 93-112.

1530 Turowski, J.M., Rickenmann, D., Dadson S.J. 2010. The partitioning of the total sediment 1531 load of a river into suspended and bedload: a review of empirical data. Sedimentology 57, $1532 \quad 1126-1146$.

1533 Twidale, C.R., 2004. River patterns and their meaning. Earth-Science Reviews 67, 159-218.

1534 Valente, C.R., Latrubesse, E.M. 2012. Fluvial archive of peculiar avulsive fluvial patterns in 1535 the largest Quaternary intracratonic basin of tropical South America: The Bananal Basin, 1536 Central-Brazil. Palaeogeography, Palaeoclimatology, Palaeoecology. DOI: $1537 \quad$ 10.1016/j.palaeo.2011.10.002.

1538 Van den Berg, J.H., 1995. Prediction of channel patterns of alluvial channel patterns of 1539 alluvial rivers. Geomorphology 12, 259-279.

1540 Van de Wiel, M.J., Coulthard, T.J., 2010. Self-organized criticality in river basins: challenging 1541 sedimentary records of environmental change. Geology 38, 87-90. Doi: $1542 \quad 10.1130 / G 30490.1$

1543 Walling, D.E., 2006. Human impact on land-ocean sediment transfer by the world's rivers. 1544 Geomorphology 79, 192-216.

1545 Walling, D.E., Quine, T.A., 1993. Using Chernobyl-derived fallout radionuclides to investigate 1546 the role of downstream conveyance losses in the suspended budget of the River Severn, 1547 United Kingdom. Physical Geography 14, 239-253. 
1548 Wang, H., Saito, Y., Zhang, Y., Naishuang, B., Sun, X., Yang, Z., 2011. Recent changes of 1549 sediment flux to the western Pacific Ocean from major rivers in East and Southeast Asia.

1550 Earth-Science Reviews. Doi: 10.1016/j.earscirev.2011.06.003.

1551 Warburton, J., Davies, T.R.H., Mandl, M.G. 1993. A meso-scale field investigation of channel 1552 change and floodplain characteristics in an upland braided gravel-bed river, New Zealand.

1553 In: Best, J.L., Bristow, C.S. (Eds.), Braided Rivers. Geological Society of London Special 1554 Publication 75, 241-255.

1555 Wasson, R.J., 2012. Geomorphic histories for river and catchment management. 1556 Philosophical Transactions of the Royal Society A 370, 2240-2263. DOI: $1557 \quad 10.1098 /$ rsta.2011.0599.

1558 Weissmann, G.S., Hartley, A.J., Nichols, G.J., Scuderi, L.A., Olson, M., Buehler, H., Banteah, 1559 R., 2010. Fluvial form in modern continental sedimentary basins: Distributive fluvial $1560 \quad$ systems. Geology, 38, 39-42. doi:10.1130/G30242.1

1561 Weissmann, G.S., Hartley, A.J., Nichols, G.J. Scuderi, L.A., Olson, M.E., Buehler, H.A., 1562 Massengill, L.C., 2011. Alluvial facies distributions in continental sedimentary basins 1563 distributive fluvial systems. In: Davidson, S.K., Leleu, S., North, C.P. (Eds.), River to Rock 1564 Record: The Preservation of Fluvial Sediments and Their Subsequent Interpretation, $1565 \quad$ SEPM Special Publication, 97, 327-355.

1566 Williams, M., 2012. River sediments. Philosophical Transactions of the Royal Society A 370, 1567 2093-2122, doi 10.1098/rsta.2011.0504.

1568 Wilkinson, B.H., McElroy, B.J., 2007. The impact of humans on continental erosion and 1569 sedimentation. Geological Society of America Bulletin 119, 140-156. 
1570 Wohl, E.E., 2007. Hydrology and discharge. In: Gupta, A. (Ed.), Large Rivers: 1571 Geomorphology and Management. Wiley, Chichester, 29-44.

$1572 \mathrm{Xu}$, J., 2004. Comparison of hydraulic geometry between sand- and gravel-bed rivers in 1573 relation to channel pattern discrimination. Earth Surface Processes and Landforms 29, $1574 \quad 645-657$.

1575 Yang, D., Ye, B., Shiklomanov, A., 2004. Discharge characteristics and changes over the Ob 1576 River watershed in Siberia. Journal of Hydrometeorology 5, 595-610.

1577 Zongyuan C., Xu. K., Watanabe, M. 2007. Dynamic hydrology and geomorphology of the 1578 Yangtze River. In: Gupta, A. (Ed.), Large Rivers: Geomorphology and Management. Wiley, 1579 Chichester, 457-469 
1. (A) Sediment yield versus annual runoff, and (B) sediment yield versus catchment area for the world's largest rivers with catchment areas greater than 0.5 million $\mathrm{km}^{2}$. Data are from Milliman and Syvitski (1992) except for runoff for the Ganges and Brahmaputra that are from Shiklomanov and Rodda (2003). Runoff is expressed as annual gross discharge in $\mathrm{km}^{3} \mathrm{yr}^{-1}$ (rather than using unit discharge). This purposely discounts the influence of catchment size which does not always control the local channel pattern in large river basins. Two rivers (Irrawaddy and Magdalena) are in the top ten sediment-yield rivers but have relatively small catchment areas so are not plotted here. Note sediment yield values have been adjusted to pre-dam values for the Mississippi, Nile, Zambezi, Indus, Columbia and Rio Grande as described in Milliman and Syvitski (1992) although some of these data are probably first-order estimates.

2. Schema of domain chains for trans-continental catchments. Types are: $A=$ Mountaindominated (e.g., Amur, Mekong), B = Lateral tributary-dominated (e.g., Ganges, Mississippi, Paraná), $C=$ Headwater-dominated with foreland depositional basins (e.g., Amazon, Orinoco), D = Headwater-dominated with lowland alluvial corridor (e.g., Ob, Mackenzie), E = Alternation between depositional basins and mountain belts (e.g., Danube, Yangtze), F = Few mountainous sources (e.g., Congo, Rio Xingu). Detailed description of the domains is given in the text. taken on 24 November 2000), (B) Magdalena (image taken on 12 January 2001), (C) 
Ob (image taken on 17 September 2002), (D) Mackenzie (image taken on 7 September 2002), (E) Congo (image taken on 17 May 2003) and (F) Orinoco (image taken on 7 March 2001). All images are plotted at the same scale. Landsat imagery courtesy of the U.S. Geological Survey.

4. Channel patterning in big rivers and examples using reaches from the 20 world's largest rivers (defined by mean annual runoff, see Table 1). Most big rivers are anabranching with a system of multiple channels that divide and rejoin but individual branch channel patterns may be straight, meandering, braided, wandering or anastomosing.

5. (A) Mariuá archipelago, upstream of the Branco tributary (mosaic taken on 5 August 2002 and 21 September 1999), and (B) the Anavilhanas islands $\sim 50 \mathrm{~km}$ upstream of Manaus (image taken on 10 July 2001), both on the Rio Negro, Brazil. Images correspond to reaches IIIb and V described in Latrubesse and Franzinelli (2005). Note in (A) the vegetated islands vary up-to-downstream from sandy, topped with muddy sediments to those that are predominantly mud, and in (B) the vegetated islands are mostly a homogeneous mix of sand, silt and clay that probably owe their origin to former conditions when elongated levees were built in water loaded with suspended sediment (interpretation and description from Latrubesse and Franzinelli (2005)). 
1627 6. Alluvial exchanges in large rivers: deposition on the floodplain (a-e), exchanges involving main channels (f-i) and deposition within them (h), or material input from

1629 tributaries (j).

7. (A) Rio Paraná near Esquina (image taken on 2 April 2001), and (B) Amazon near Manacapuru (image taken on 21 January 2003), showing a range of adjacent standing water bodies that may be refilled during floods. Labels are: $1=$ swale ponds, $2=$ cutoff channels, 3 = floodbasins (ponded between raised alluvial ridges or against valleysides), $4=$ ponded tributary valleys. More details on the origin, evolution and types of floodplain water bodies for the Paraná are in Paira and Drago (2007). See Table 1 for a list of the type of standing water bodies found in the 20 largest rivers in the world. Landsat imagery courtesy of the U.S. Geological Survey.

8. The four main hydraulic systems, with examples, that characterise large rivers: (A) Type 1: lacustrine-dominated; (B) Type 2: mainstream-dominated; (C) Types 3(a)-(b): equi-style and contra-style (tributary or accessory stream dominated); (D) Type 4: confined or bedrock-dominated. Landsat imagery courtesy of the U.S. Geological Survey and all images are plotted at the same scale.

9. The Amur at Malyshevo (image taken on 5 September 2002) showing an example of accessory channels that run alongside the main channel that can be of a different channel pattern from the main stem. Landsat imagery courtesy of the U.S. Geological Survey. Darker brown colours in the main and accessory channels represent zones of 
lower velocity and sediment load and potential areas for deposition. Label $1=$ accessory channel.

10. (A) Map showing upper course of the River Ob and locations of points referred to in text, (B) River Ob at Krivosheino taken on 7 July 1999, (C) River Ob at Ust'-Tym taken on 27 September 2010, (D) River Ob at Alekino taken on 21 May 2003. Landsat imagery courtesy of the U.S. Geological Survey. Note (B) shows the multiplicity of channels with different radius of curvature associated with several styles of meander development. Lateral accretion dominates floodplain construction and avulsion is controlled by the strong, local floodplain relief, $(\mathrm{C})$ shows the slow rates of meander migration and scroll bar accretion, and (D) shows the complexity of floodplain relief that favours meander-bend avulsion. Labels for standing water bodies are $1=$ in point bar swales, 2 = in arcuate dead channel loops, 3 = as broader unsedimented water bodies, 4 = in circular thaw ponds and thermokarst features.

11. Braided river planform of the Jamuna River, Bangladesh and locations referred to in the text. Images courtesy of U.S. Geological Survey and mosaic taken at low flow on

12. Channel change on the Jamuna River near Sirajganj. Images taken on (A) 13 February 1989, (B) 19 February 2000, (C) 4 November 2004, and (D) 21 January 17 February 2002 and 24 February 2002. 2010. Note image (C) is taken following the discharge peak that usually occurs in August. Labels on (B) are $1=$ unit bars, $2=$ compound bar, $3=$ vegetated islands. The 
main channels are generally 'clean' and devoid of emergent unit bars. The Jamuna reworks most of its active braidbelt in less than 10 years.

13. (A) The anabranching Rio Paraná, Argentina and locations referred to in the text, (B) Puerto Reconquista offtake, and (C) Colastine offtake. Images courtesy of U.S. Geological Survey and mosaic taken on 26 December 2002, 8 April 2003, 15 April 2003, 3 May 2003 and 24 May 2003.

14. Channel change on the Rio Paraná between 1972 and 2010 in a reach 25 km southeast of Santa Fe (location in Fig. 13A). Images courtesy of U.S. Geological Survey and taken on dates shown in Figure. Label 1 on 2 December 1991 image is the new mid-channel bar that was probably created in the 1983 flood (see Fig. 16) and is pictured fully emergent in Fig. 15.

1686

15. View of $2.5 \mathrm{~km}$-long mid-channel bar near Santa Fe that developed in the mid-1980s (bar location labelled in Fig. 14). Note the dune field on the incipient sand bar at the main bartail. Photograph taken on 1 October 2010.

16. Channel change in the Rio Paraná from 1905-2010 reproduced from historic and recent bathymetric surveys (data courtesy of Prof. M. Amsler,Dr R. Szupiany and Dirección Nacional de Vias Navegables). All data are reduced to the same common datum. The $18 \mathrm{~km}$-reach is $25 \mathrm{~km}$ south-east of Santa Fe and satellite images of 
1695 planform change since 1972 are presented in Fig. 14. Label $1=$ mid-channel bar 1696 shown in Figs 14 and 15.

1697 Table captions

1698

1699 1. Reach character on the world's 20 largest rivers 


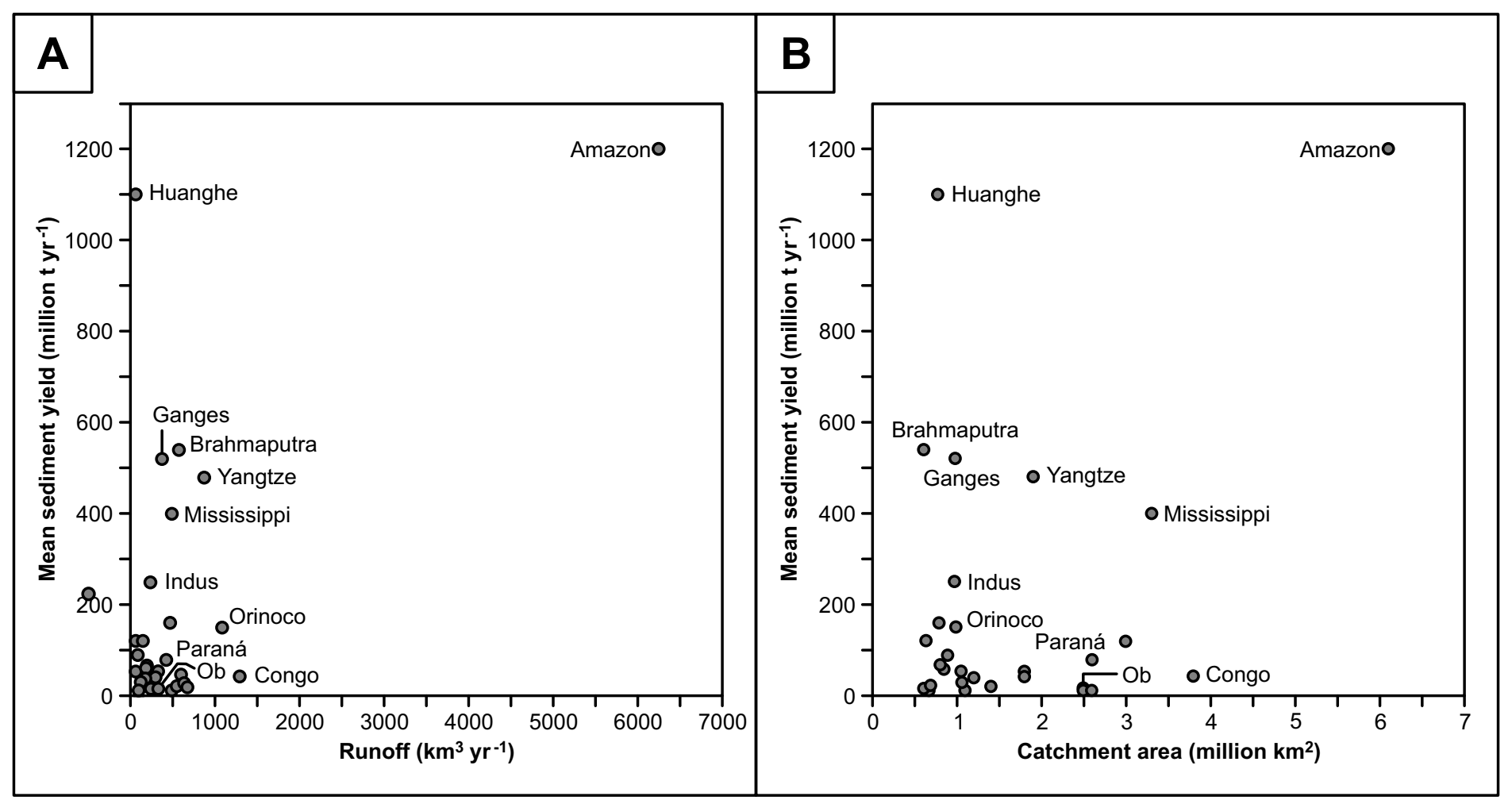




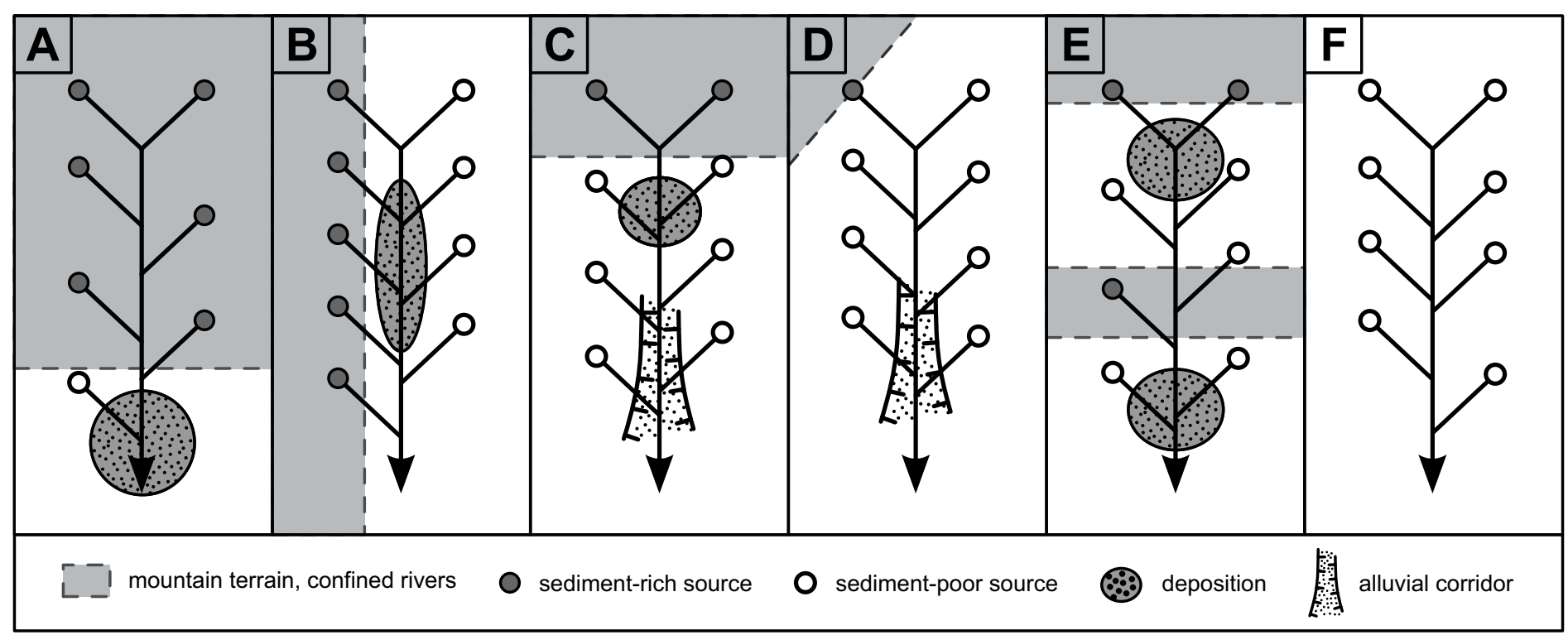




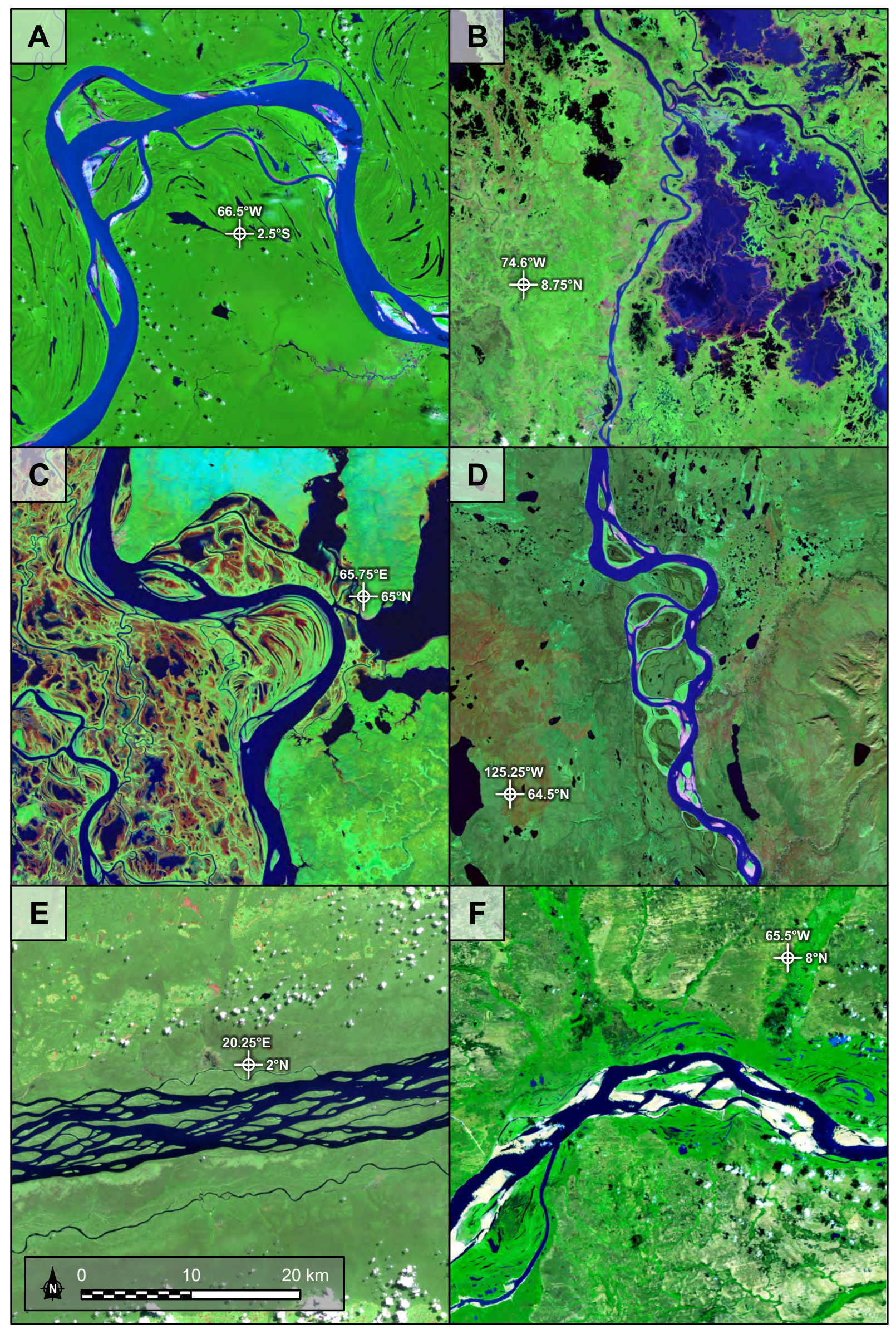




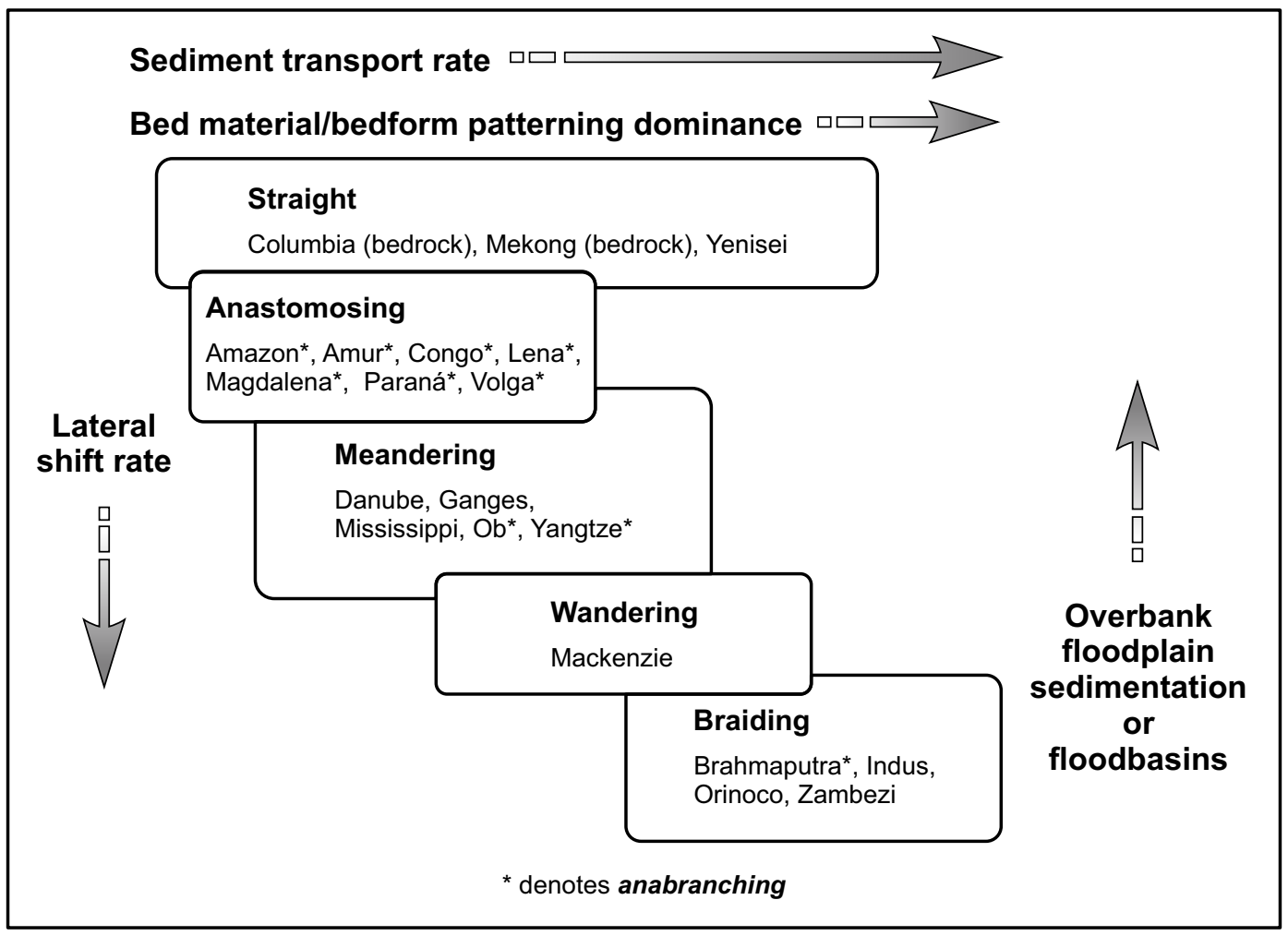




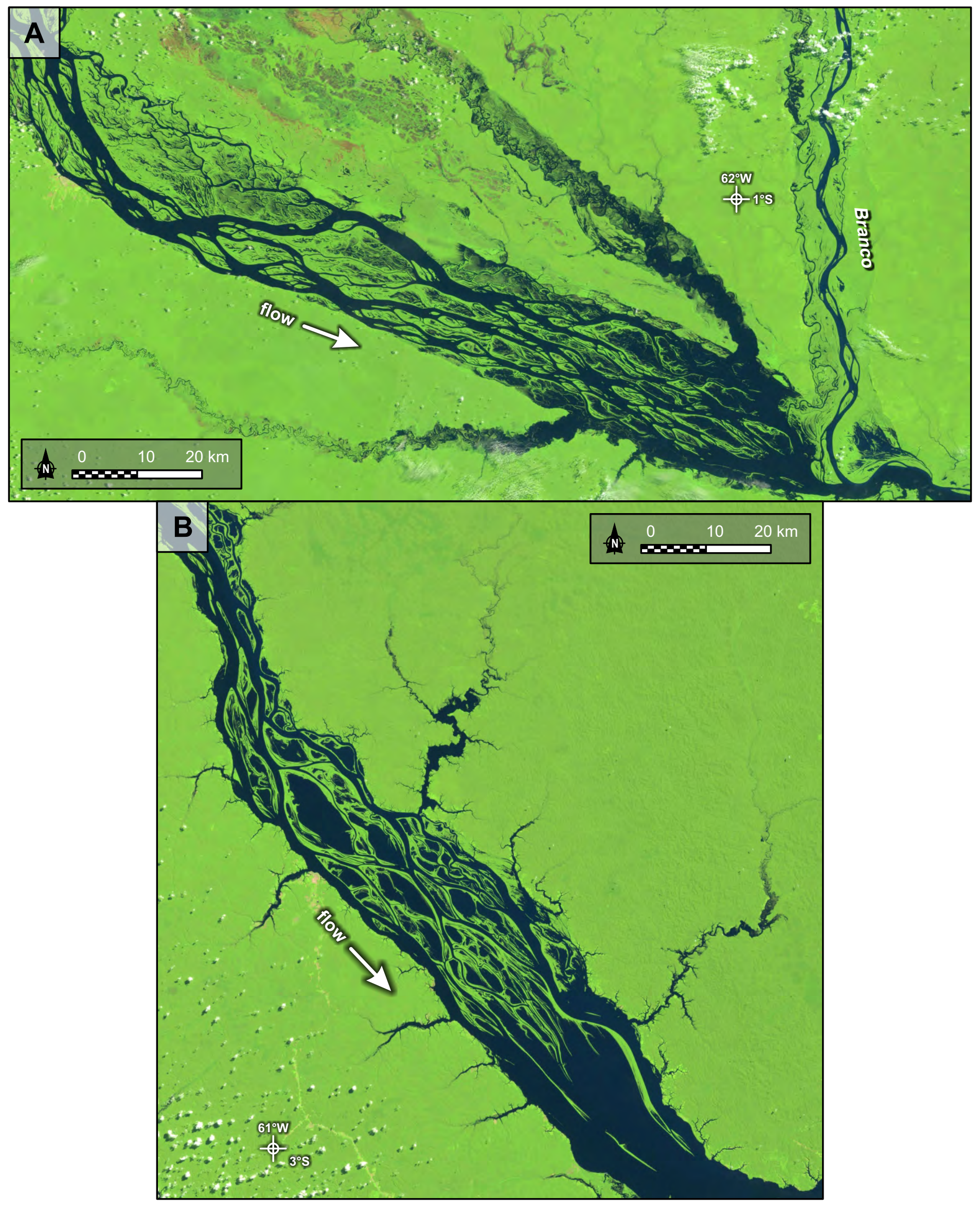




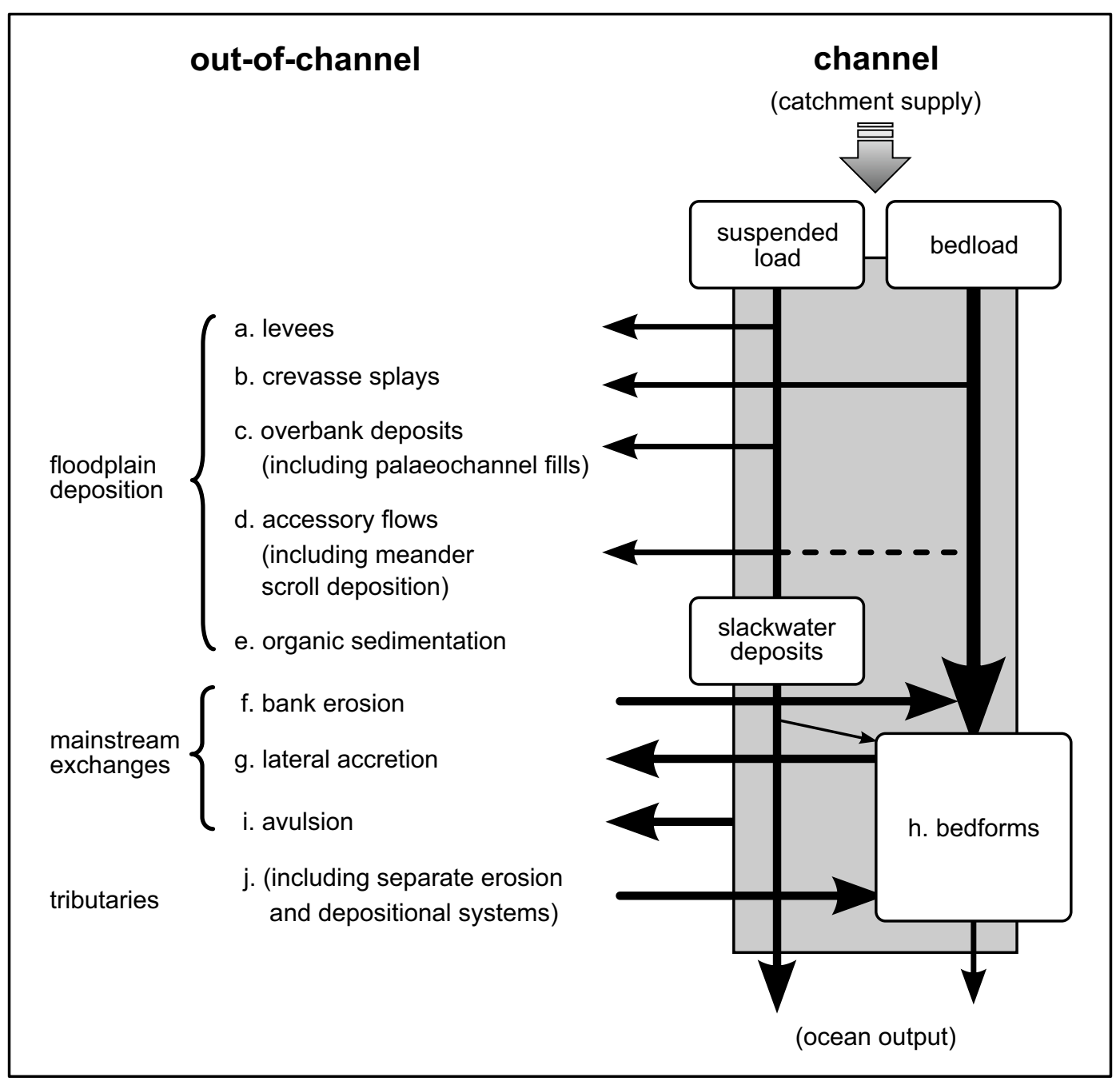




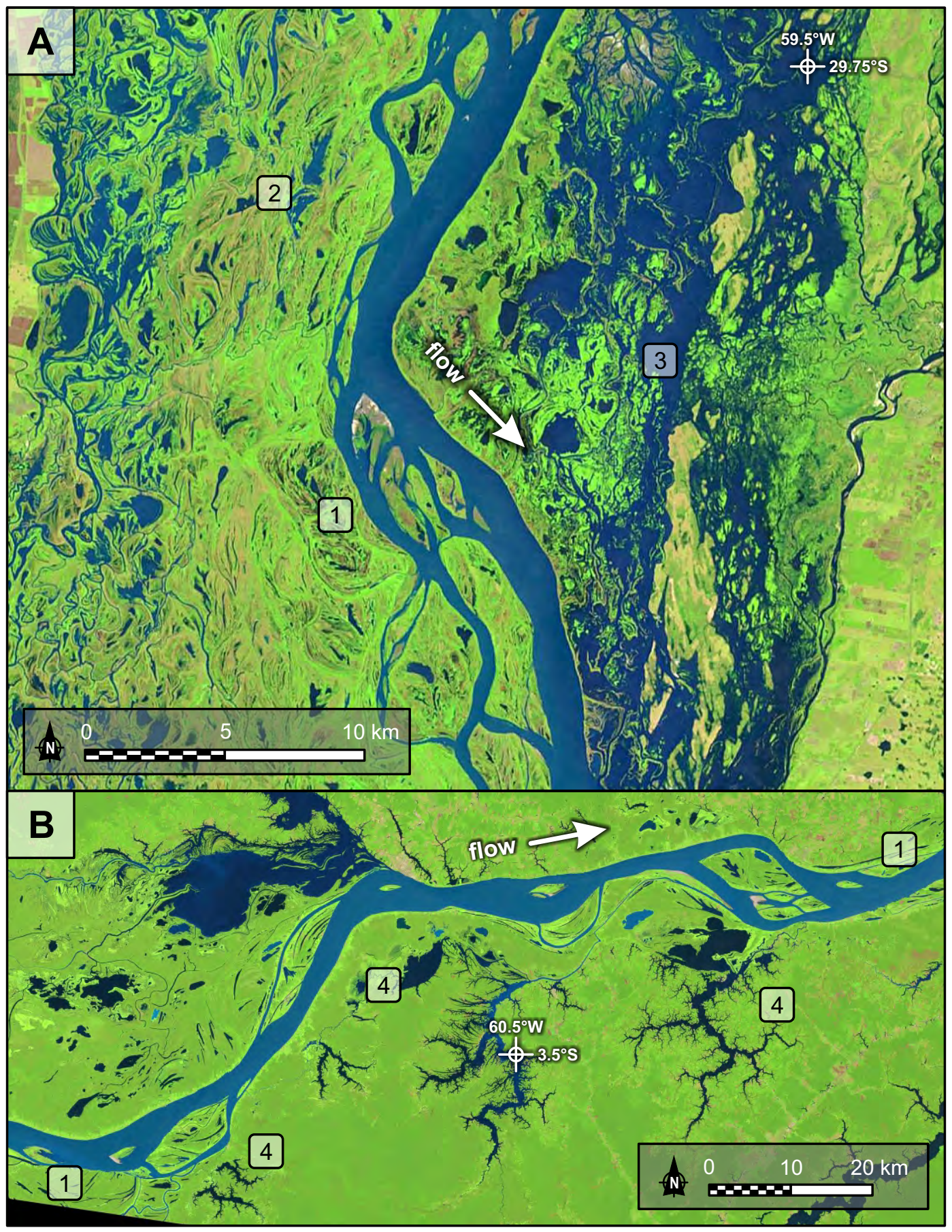




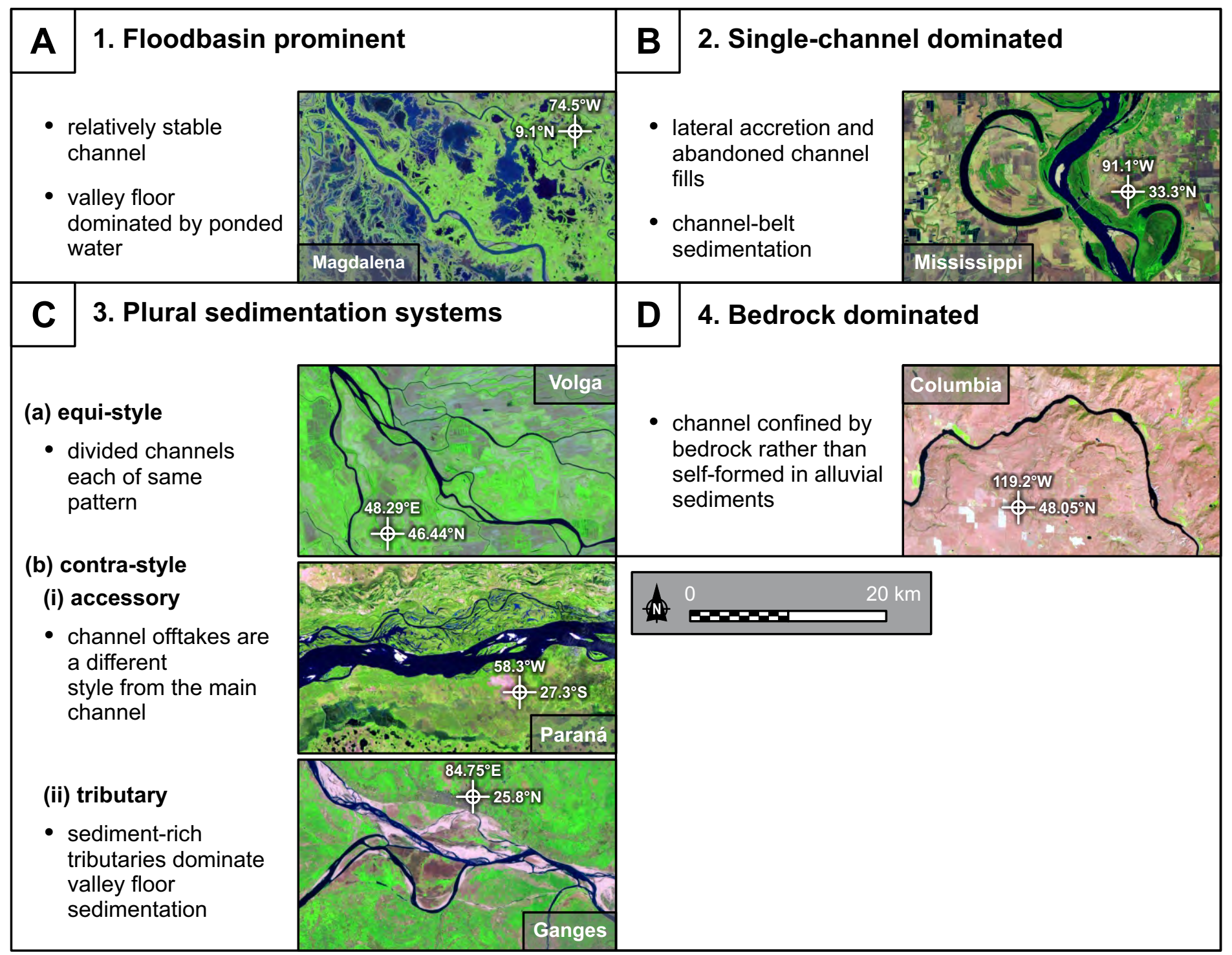




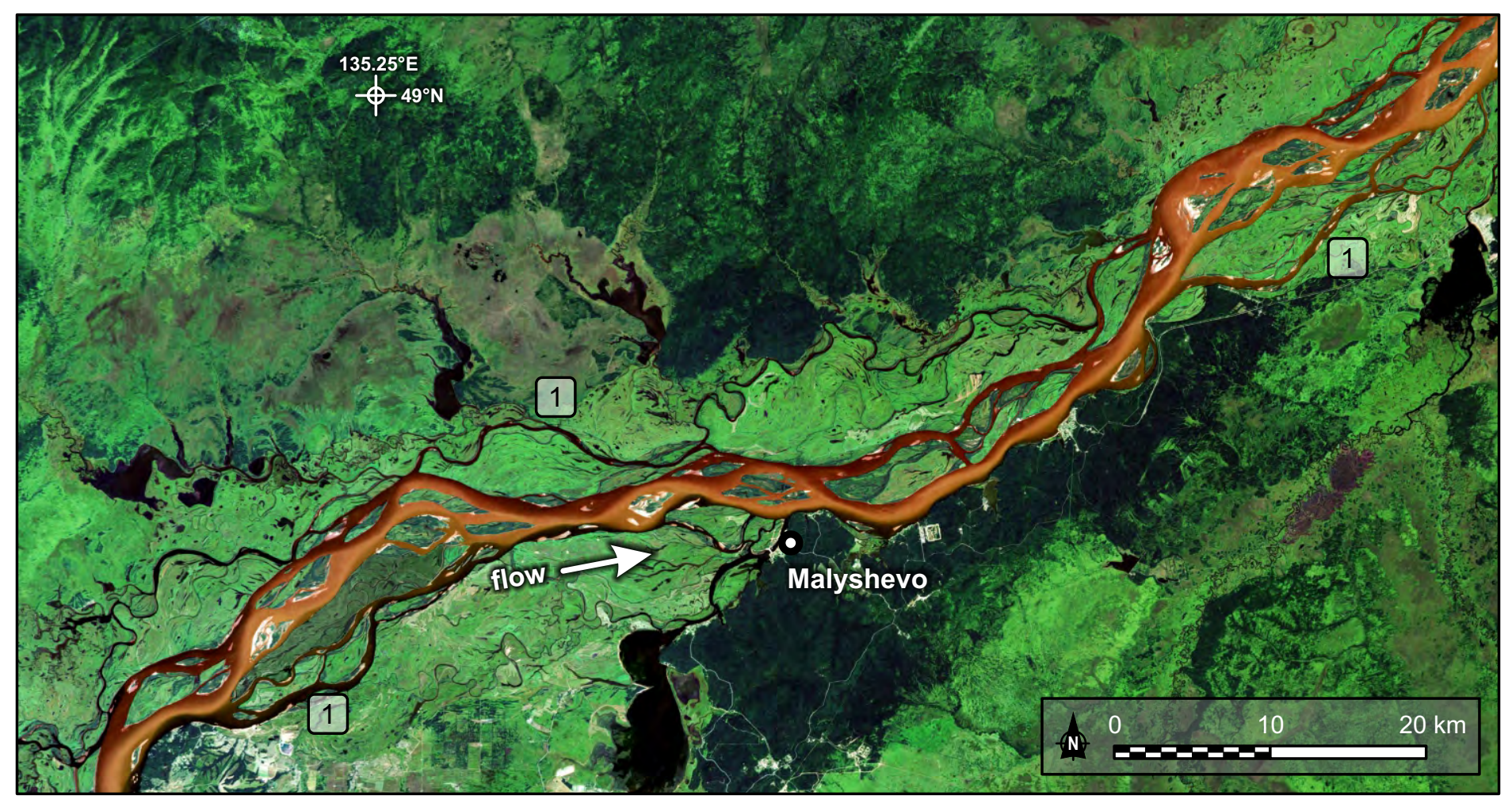




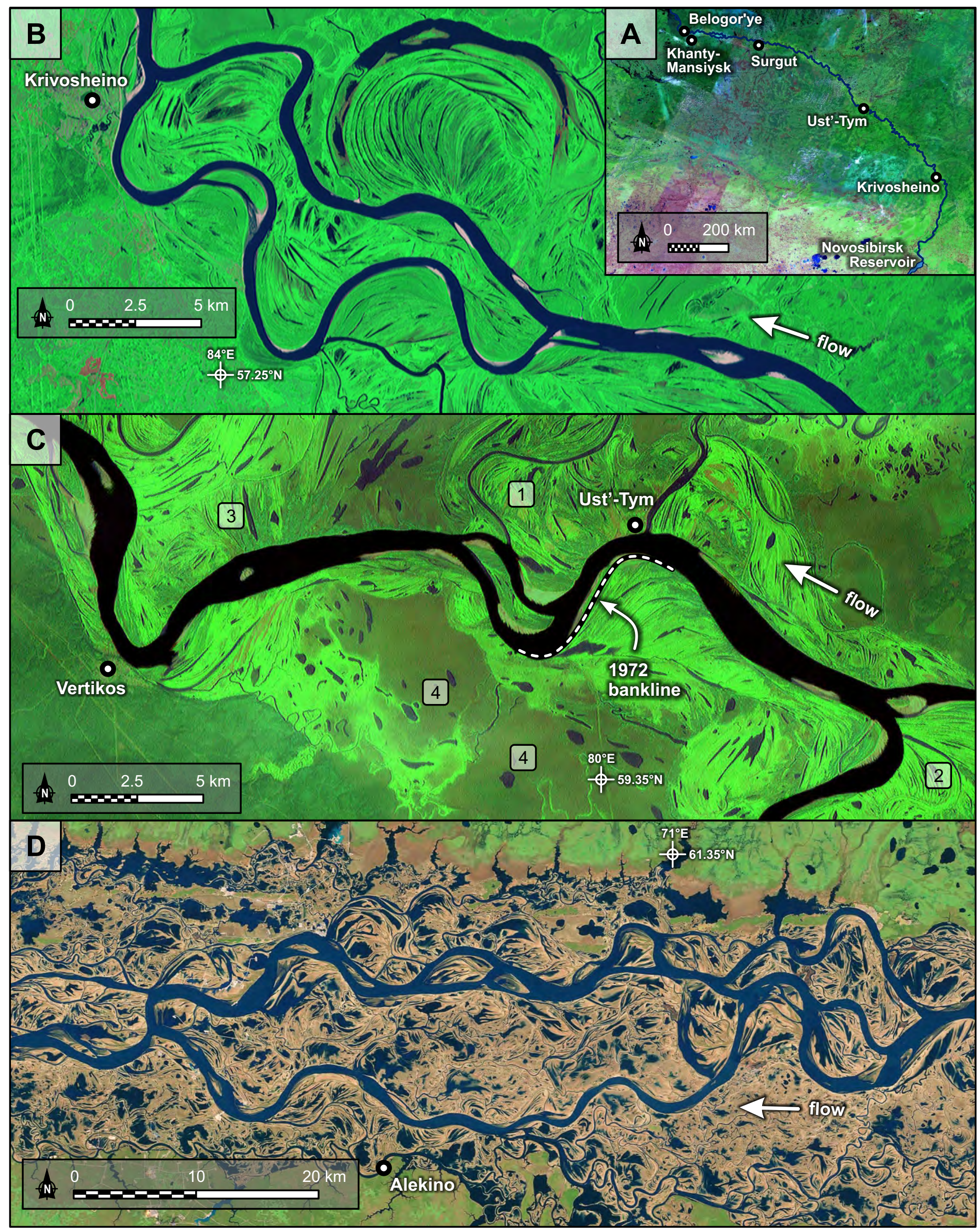




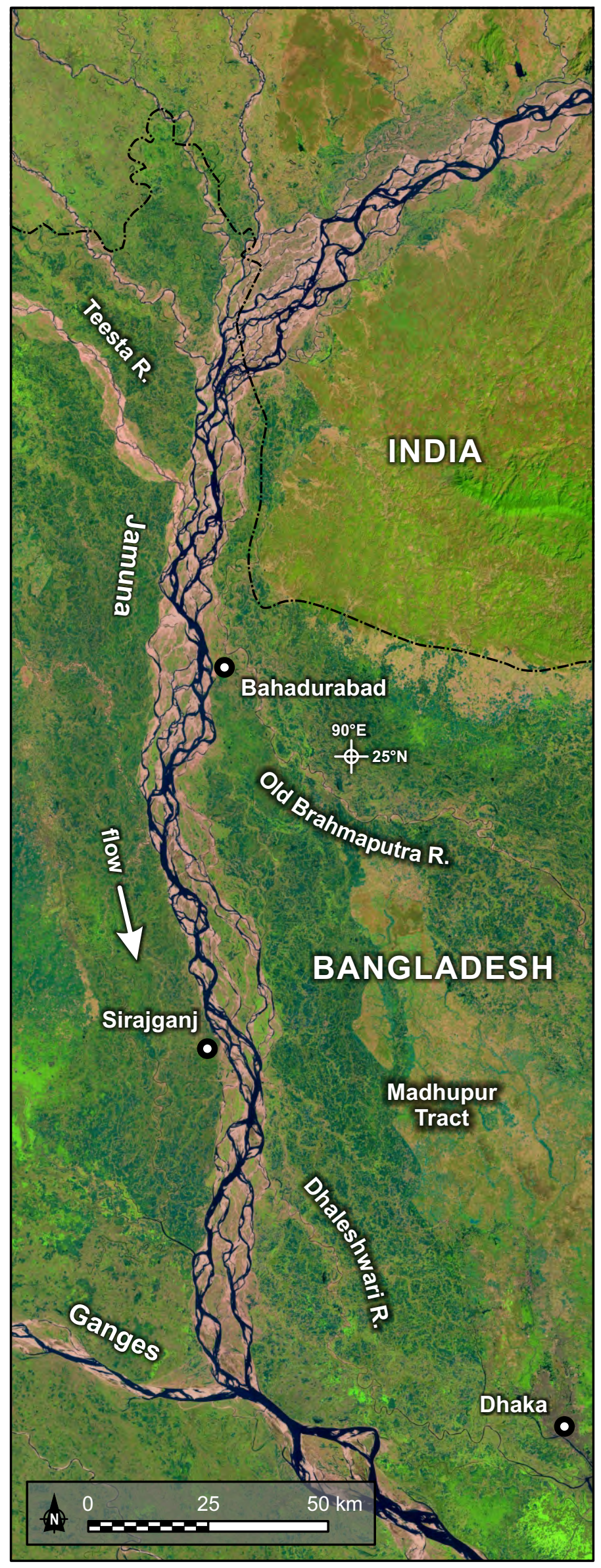




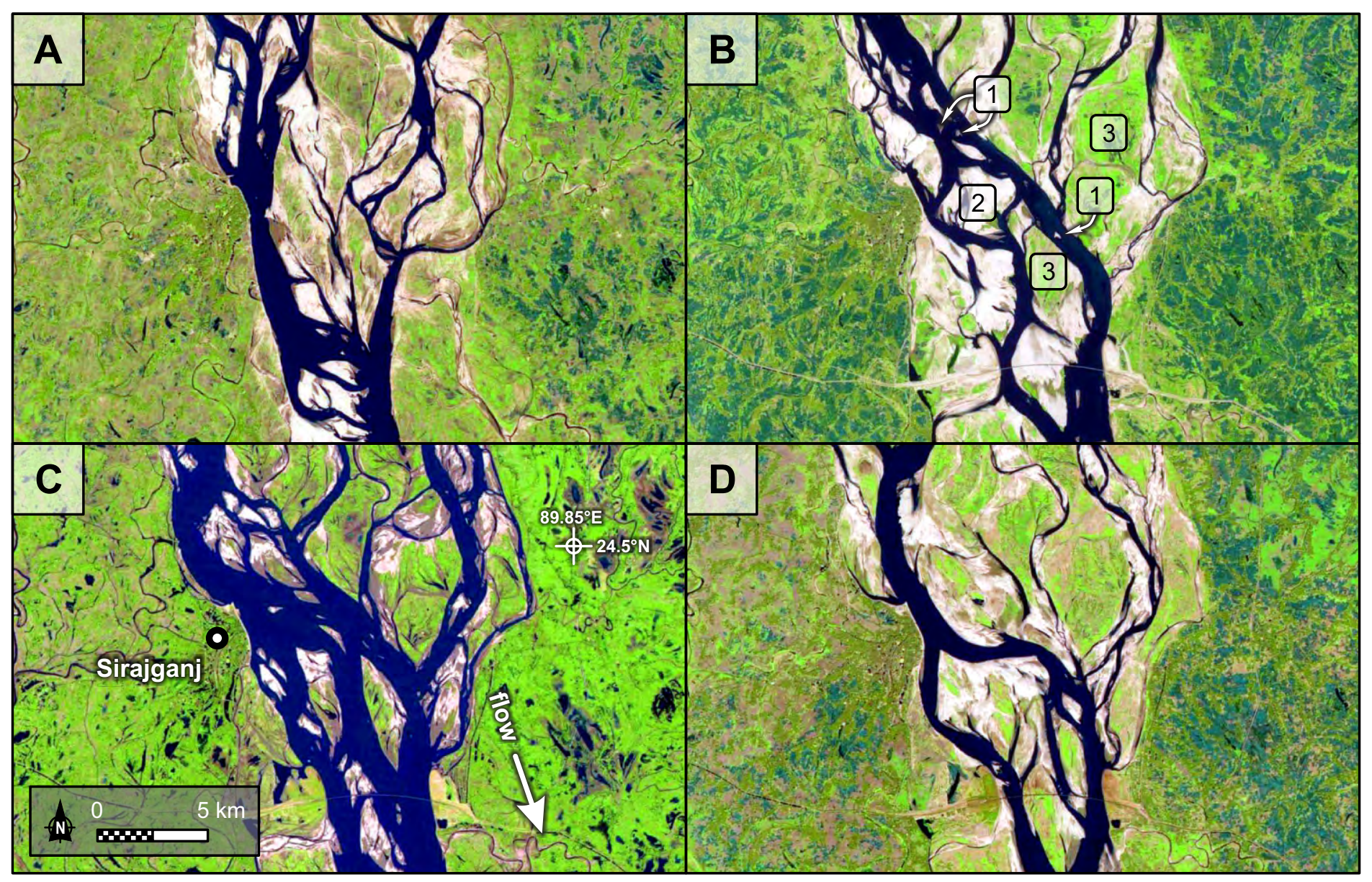




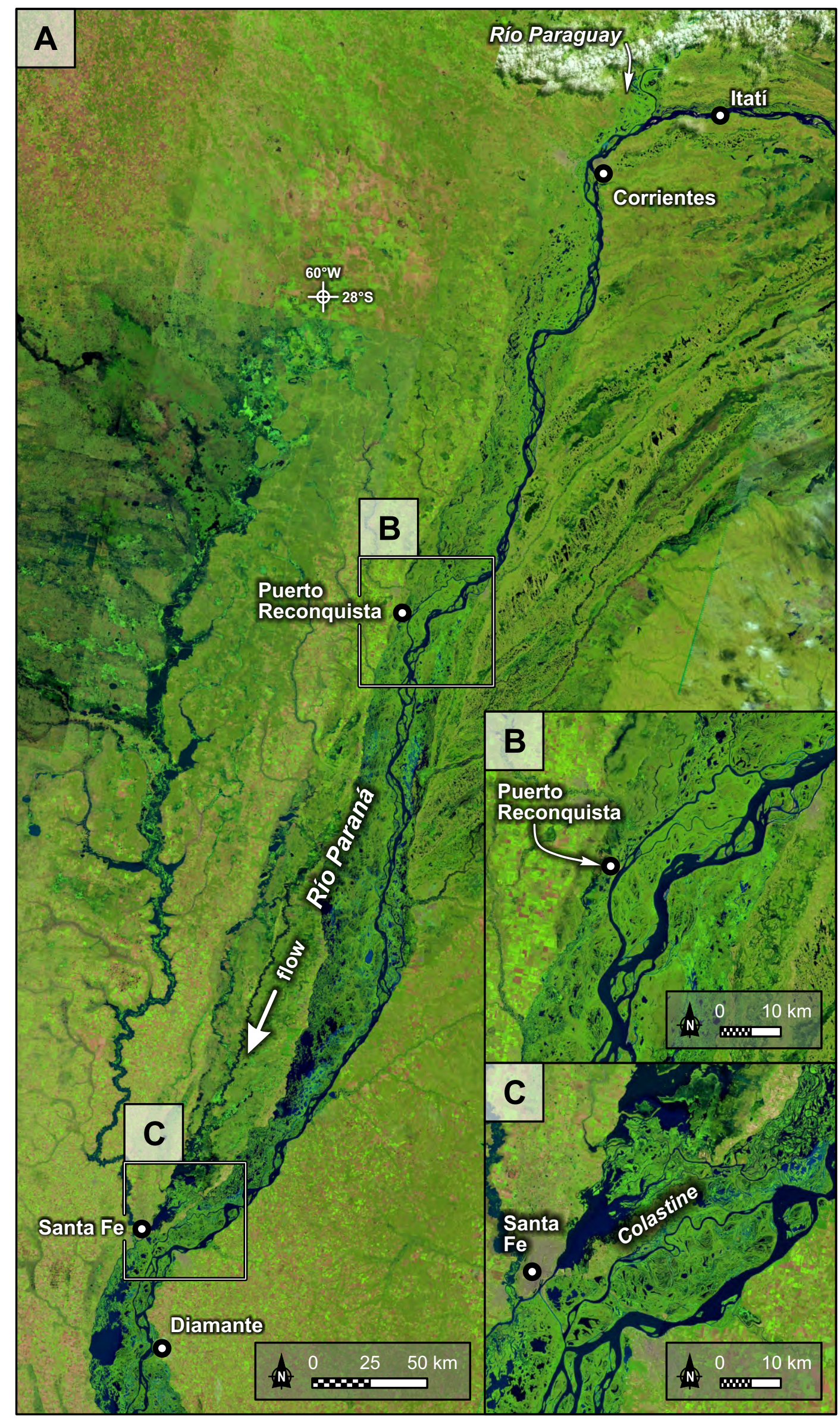




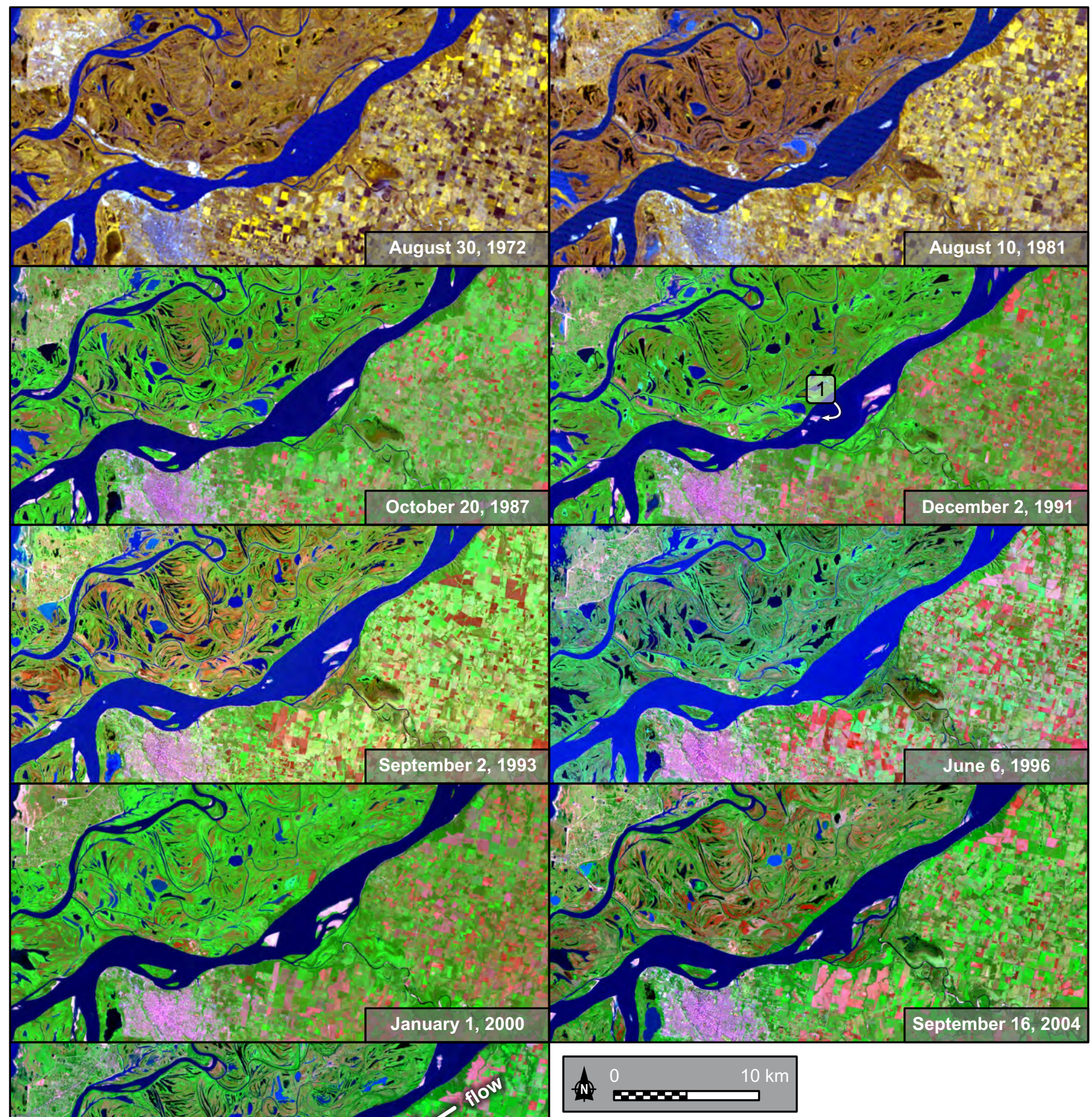




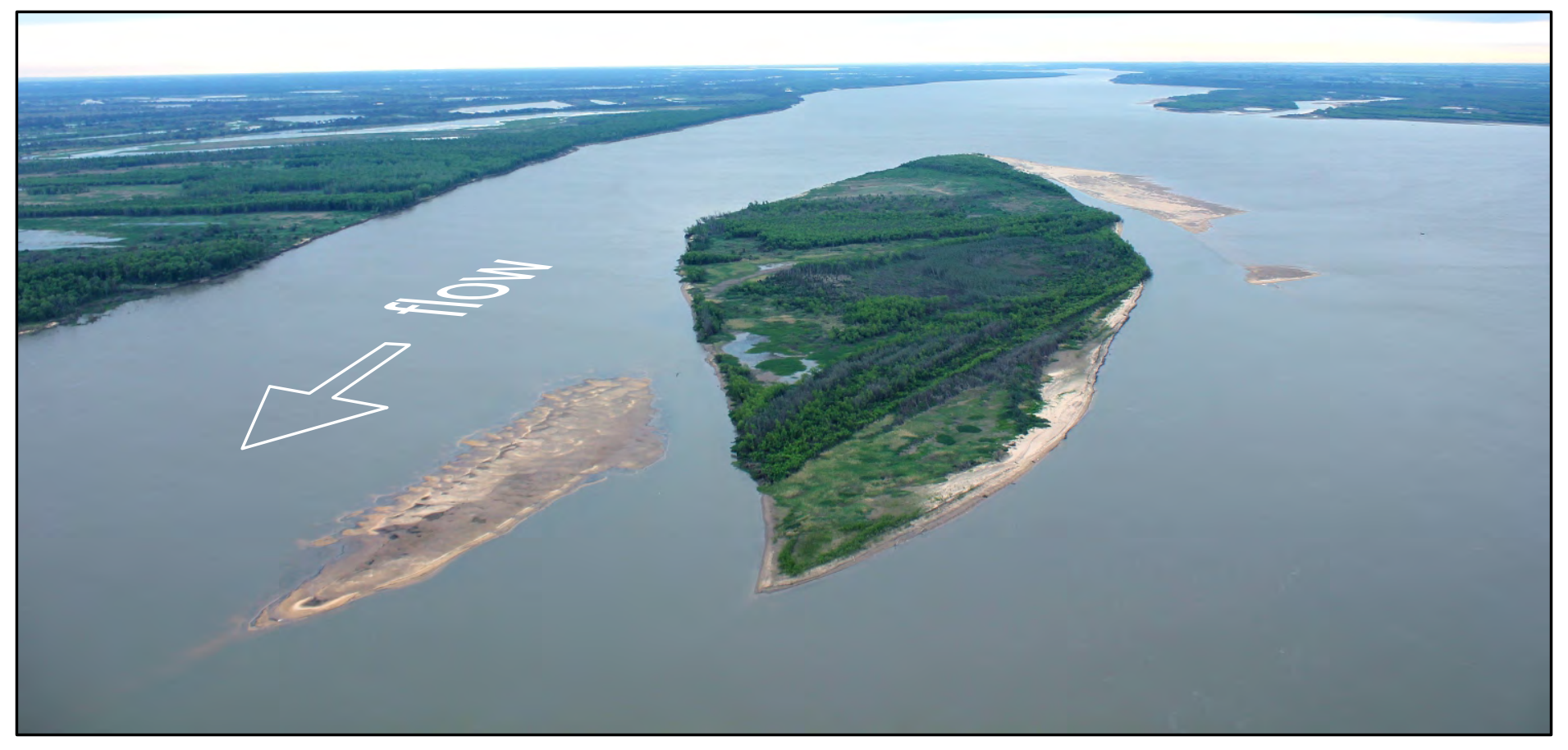




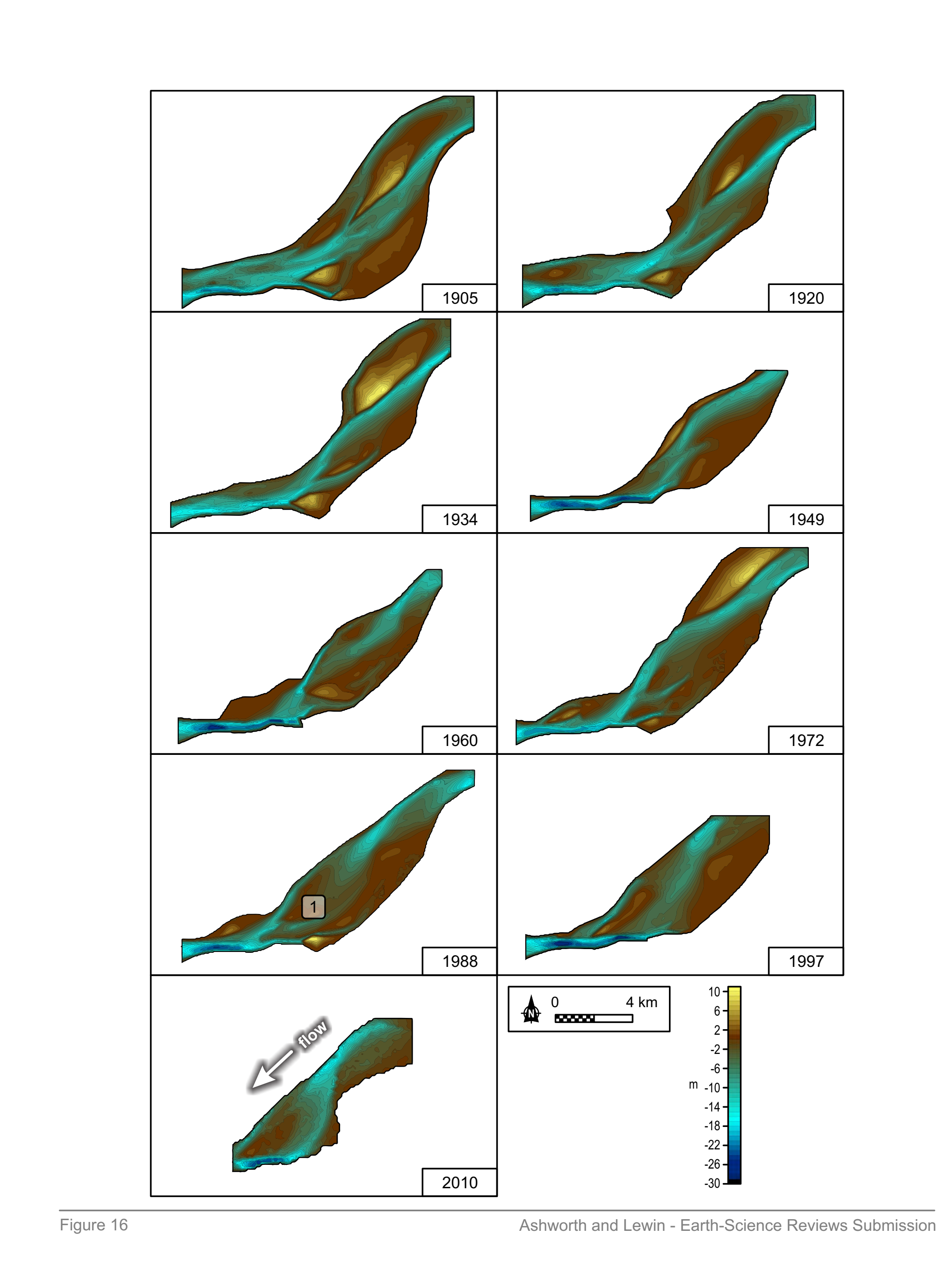




\begin{tabular}{|c|c|c|c|c|c|c|c|c|c|c|c|c|c|}
\hline \multirow[b]{4}{*}{ Amazon } & \multirow{3}{*}{$\begin{array}{l}\text { Mean annual } \\
\text { runoff }(1) \\
\left(10^{9} \mathrm{~m}^{3}\right)\end{array}$} & \multirow{3}{*}{\multicolumn{2}{|c|}{$\begin{array}{c}\text { Reach } \\
\text { location }\end{array}$}} & \multirow{4}{*}{$\begin{array}{c}\begin{array}{c}\text { Gradient } \\
\left(\mathrm{m} \mathrm{km}^{-1}\right)^{(6)}\end{array} \\
0.10\end{array}$} & \multirow{4}{*}{$\begin{array}{c}\begin{array}{c}\text { Valley } \\
\text { floor } \\
\text { width } \\
(\mathbf{k m})^{(7)}\end{array} \\
50 \\
\end{array}$} & \multirow{4}{*}{$\begin{array}{c}\begin{array}{c}\text { Mainstream } \\
\text { character }^{(2)}\end{array} \\
{ }^{*} \mathrm{M} / \mathrm{A}\end{array}$} & \multirow{4}{*}{$\begin{array}{c}\begin{array}{c}\text { Channel } \\
\text { width } \\
\text { (km) }\end{array} \\
2.5 \\
\end{array}$} & \multirow{2}{*}{\multicolumn{4}{|c|}{$\begin{array}{l}\text { Sedimentation elements }{ }^{(3)} \\
\text { Floodplain } \quad \text { Mainstream Tribs }\end{array}$}} & \multirow{3}{*}{$\begin{array}{l}\text { Surface } \\
\text { waters }^{(4)}\end{array}$} & \multirow{3}{*}{$\begin{array}{c}\text { Hydraulic } \\
\text { system } \\
\text { (Fig. 8) }\end{array}$} \\
\hline & & & & & & & & & & & & & \\
\hline & & & & & & & & \multirow{2}{*}{$\begin{array}{l}a \\
0\end{array}$} & $\begin{array}{llll}b & c & d & e\end{array}$ & $\begin{array}{llll}f & g & h & i\end{array}$ & j & & \\
\hline & 6246 & $2^{\circ} 33^{\prime} \mathrm{S}$ & $66^{\circ} 30^{\prime} \mathrm{W}$ & & & & & & 0.00 & 00 & $\circ$ & $1,2,4$ & $1,2,3(b)(i)$ \\
\hline Congo & 1292 & $2^{\circ} 09^{\prime} \mathrm{N}$ & $21^{\circ} 36^{\prime} \mathrm{E}$ & 0.14 & $10-26$ & ${ }^{*} \mathrm{~A}$ & $4.8^{+}$ & 0 & $\begin{array}{llll}0 & 0 & 0 & 0\end{array}$ & 0000 & $\circ$ & - & 2 \\
\hline Orinoco & 1089 & $7^{\circ} 53^{\prime S}$ & $65^{\circ} 30^{\prime} \mathrm{W}$ & 0.04 & 8 & B & 2.6 & 0 & 00000 & 0 & $\circ$ & 1,2 & $3(a)$ \\
\hline Yangtze (Changjiang) & 872 & $30^{\circ} 37^{\prime} \mathrm{N}$ & $117^{\circ} 13^{\prime} \mathrm{E}$ & - & 15 & ${ }^{*} \mathrm{M} / \mathrm{A}$ & 2.5 & 0 & 0000 & 0000 & 0 & $1,2,3,4$ & 1,2 \\
\hline Brahmaputra & 574 & $25^{\circ} 50^{\prime} \mathrm{N}$ & $89^{\circ} 39^{\prime} \mathrm{E}$ & 0.22 & 20 & ${ }^{*} \mathrm{~B}$ & $12.0+$ & 0 & 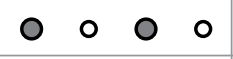 & 000 & 0 & 1 & $3(a)$ \\
\hline Yenisei & 572 & $65^{\circ} 16^{\prime} \mathrm{N}$ & $87^{\circ} 56^{\prime} \mathrm{E}$ & - & 9 & s & 2.4 & 0 & 00 & 0000 & $\circ$ & 1 & 2 \\
\hline Volga & 560 & $57^{\circ} 07^{\prime} \mathrm{N}$ & $47^{\circ} 18^{\prime} \mathrm{E}$ & 0.08 & 18 & ${ }^{*} \mathrm{~A}$ & - & 0 & 0000 & $\begin{array}{llll}0 & 0 & 0 & 0\end{array}$ & 0 & 1,2 & $3(a)$ \\
\hline Zambezi ${ }^{(5)}$ & 546 & $17^{\circ} 57^{\prime} \mathrm{S}$ & $35^{\circ} 30^{\prime} \mathrm{E}$ & 0.22 & 9 & ${ }^{*} \mathrm{~B}$ & 0.80 & 0 & 0000 & 0 & o & 1,2 & $3(a)$ \\
\hline Lena & 512 & $62^{\circ} 42^{\prime} \mathrm{N}$ & $129^{\circ} 49^{\prime} \mathrm{E}$ & 0.06 & 14 & ${ }^{*} \mathrm{~A}$ & 2.30 & 0 & 0000 & 0 & $\circ$ & 1,2 & $2,3(b)(i)$ \\
\hline Mississippi $^{(5)}$ & 495 & $32^{\circ} 43^{\prime} \mathrm{N}$ & $91^{\circ} 09^{\prime} \mathrm{W}$ & 0.06 & $50+$ & $\mathrm{M}$ & 1.50 & 0 & 0000 & 00 & 0 & 1,2 & 2 \\
\hline Mekong & 466 & $14^{\circ} 00^{\prime} \mathrm{N}$ & $105^{\circ} 53^{\prime} \mathrm{E}$ & 0.46 & 10 & * & 1.80 & & (mostly b & edrock) & & - & 4 \\
\hline Paraná & 429 & $31^{\circ} 41^{\prime} \mathrm{S}$ & $60^{\circ} 33^{\prime} \mathrm{W}$ & 0.06 & 28 & ${ }^{*} \mathrm{~A}$ & 2.20 & 0 & 0000 & 0000 & 0 & $1,2,3,4$ & 1,3(b)(i)(ii) \\
\hline Ob & 400 & $58^{\circ} 22^{\prime} \mathrm{N}$ & $82^{\circ} 43^{\prime} \mathrm{E}$ & 0.04 & 21 & ${ }^{*} \mathrm{M}$ & 0.90 & 0 & 0000 & 00 & 0 & 1,2 & $3(a)$ \\
\hline Ganges & 380 & $25^{\circ} 24^{\prime} \mathrm{N}$ & $83^{\circ} 10^{\prime} \mathrm{E}$ & 0.08 & 10 & $\mathrm{M}$ & 1.00 & 0 & 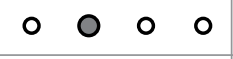 & 00 & $\circ$ & - & 2 \\
\hline Amur & 324 & $48^{\circ} 48^{\prime} \mathrm{N}$ & $135^{\circ} 46^{\prime} \mathrm{E}$ & 0.36 & 11 & ${ }^{*} \mathrm{~A} / \mathrm{B}$ & 2.60 & 0 & 0000 & 0 & 0 & $1,2,3,4$ & 3(b)(i)(ii) \\
\hline Mackenzie & 306 & $64^{\circ} 38^{\prime} \mathrm{N}$ & $125^{\circ} 03^{\prime} \mathrm{W}$ & 0.38 & 6 & ${ }^{*} \mathrm{~W}$ & 1.20 & 0 & 0000 & o & 0 & - & $3(a)$ \\
\hline Columbia & 251 & $45^{\circ} 47^{\prime} \mathrm{N}$ & $120^{\circ} 04^{\prime} \mathrm{W}$ & 0.26 & 2 & S & 1.80 & & (mostly b & edrock) & & - & 4 \\
\hline Indus & 238 & $27^{\circ} 20^{\prime} \mathrm{N}$ & $68^{\circ} 15^{\prime} \mathrm{E}$ & 0.14 & $90+$ & ${ }^{*} \mathrm{~B} / \mathrm{M}$ & 1.10 & 0 & 0000 & 0 & 0 & 2 & $3(b)(i i)$ \\
\hline Magdalena & 238 & $8^{\circ} 55^{\prime} \mathrm{N}$ & $74^{\circ} 29^{\prime} \mathrm{W}$ & - & $25+$ & ${ }^{*} \mathrm{~A}$ & 0.70 & 0 & 0000 & 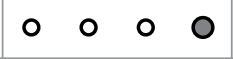 & 0 & $2,3,4$ & $1,3(a)$ \\
\hline Danube & 203 & $46^{\circ} 15^{\prime} \mathrm{N}$ & $18^{\circ} 55^{\prime} \mathrm{E}$ & 0.20 & 15 & M & 0.60 & 0 & 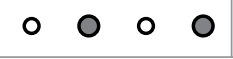 & 0000 & 0 & 1,2 & 2 \\
\hline
\end{tabular}

${ }^{(1)}$ From Milliman and Syvitski (1992) with unit adjustment; separate figures for Ganges and Brahmaputra from Shiklomanov and Rodda (2003)

${ }^{(2)}$ Main channels may be anabranching $\left({ }^{*}\right)$, anastomosing $(A)$ or wandering $(W)$. Single channels or sub-branches may be straight $(S)$, actively meandering (M) or braided (B)

${ }^{(3)}$ Sedimentation elements (a-j) are given in Figure 6 ( dominant, O present, o not significant)

${ }^{(4)}$ Surface waters may be in: 1 scroll ponds, 2 cutoff channels, 3 floodbasins (ponded between raised alluvial ridges or against valley-sides), 4 ponded tributary valleys

${ }^{(5)}$ Runoff adjusted for regulation as described in Milliman and Syvitski (1992)

${ }^{(6)}$ Gradients measured over $50 \mathrm{~km}$ on adjacent flooplain using GoogleEarth ( - indicates so flat it is unquantifiable)

${ }^{(7)}$ Channel widths (+ including bars/islands) and valley floor widths (that may include low terraces) are locally very variable; figures give an approximate guide 